\title{
Technological and Mobility Trends in E-Government
}

\author{
Ali M. Al-Khouri ${ }^{1}$ \\ ${ }^{1}$ Emirates Identity Authority, Abu Dhabi, UAE \& British Insitute for Technology and eCommerce, London, UK \\ Correspondence: Ali M. Al-Khouri, Emirates Identity Authority, Abu Dhabi, UAE \& British Insitute for Technology \\ and eCommerce, London, UK. E-mail: Ali.AlKhouri@emiratesid.ae
}

Received: August 7, 2013

Accepted: August 20, 2013

Online Published: August 21, 2013

doi:10.5430/bmr.v2n3p90

URL: http://dx.doi.org/10.5430/bmr.v2n3p90

\begin{abstract}
Electronic government (e-government) has been attracting the attention of the world for the past two decades, and specifically, upon the advent of the internet. Governments worldwide have spent billions of dollars to date to transform themselves into e-government. However, their efforts and large investments resulted mainly in online portals and scattered electronic services. Various studies indicate that e-government initiatives are failing to meet citizens' expectations for convenient service delivery systems. Nonetheless, the rapid pace at which technology is innovatively evolving and its disruptive nature is forcing new realities to be accepted in e-government domain. The new forms of mobility made possible by the transforming technologies are not only changing how people live their lives today, but also redefining business models, employee productivity, customer relationship, and even how governments are structured. The growing usage of smartphones and tablets have significant impact on all industries, but at large how government services are delivered. This study attempts to provide some qualitative input to the existing body of knowledge. It sheds light on some trends that have high impact to disrupt existing technological-based channels of interaction between governments and citizens, and ultimately on service delivery. It also sheds light on the role of modern identity management infrastructure in enabling higher levels of trust and confidence in mobile transactions.
\end{abstract}

Keywords: E-government, Digital identity, Mobile government, NFC technology, Identity management

\section{Introduction}

Today's world is going through rapid transformation owing to the fast pace of change in technological development and adoption. The constant evolution in the field of technology is pushing governments and businesses alike to move from a product-based to an information-based mentality and practice. However, this is not easy to achieve in light of the vacuum of revolutionary digital concepts and substances with which we live. Success in the e-government domain is very much determined by the agility and flexibility of organizations to evaluate and strategically align their businesses to the growing choices of enabling technologies.

In principle, enabling technologies can come in two forms: sustaining or disruptive innovation (Christensen, 1997; 2003). Sustaining innovation are those existing but incrementally evolving technologies that can be incorporated into present practices and structures of organizations to establish a positive and sustainable impact on capabilities, business operations, and models. On the other hand, disruptive innovation simply forces changes in existing business practices and models, bringing a new twist to existing markets and technologies, and displaces them over time. The effect of disruptive innovation is new and revolutionary.

In practice, organizations get locked-in with their legacy systems and technologies, and usually get used to focusing on development possibilities of such legacies. Such systems and technologies may well help organizations, for instance, to improve performance in marketing, sales, and customer support, lower costs, and improve margins, among other ways. However, disruptive innovation attempts to bring to niche markets similar capabilities, but adds real value to customers (Piao \& Okhuysen, 2012). In other words, disruptive innovation seeks to offer a technology that pays higher attention to simplicity, convenience, ability to customize, and/or price dimensions (Dombrowski \& Gholz, 2009; Robb, 2006). Disruptive innovation is about delivering innovations aimed at a set of customers whose needs are being ignored (Gilbert, 2012). As depicted in Figure 1, once a truly disruptive product or service takes root in simple applications at the bottom of a market, it can move relentlessly up market, eventually displacing established competitors. 


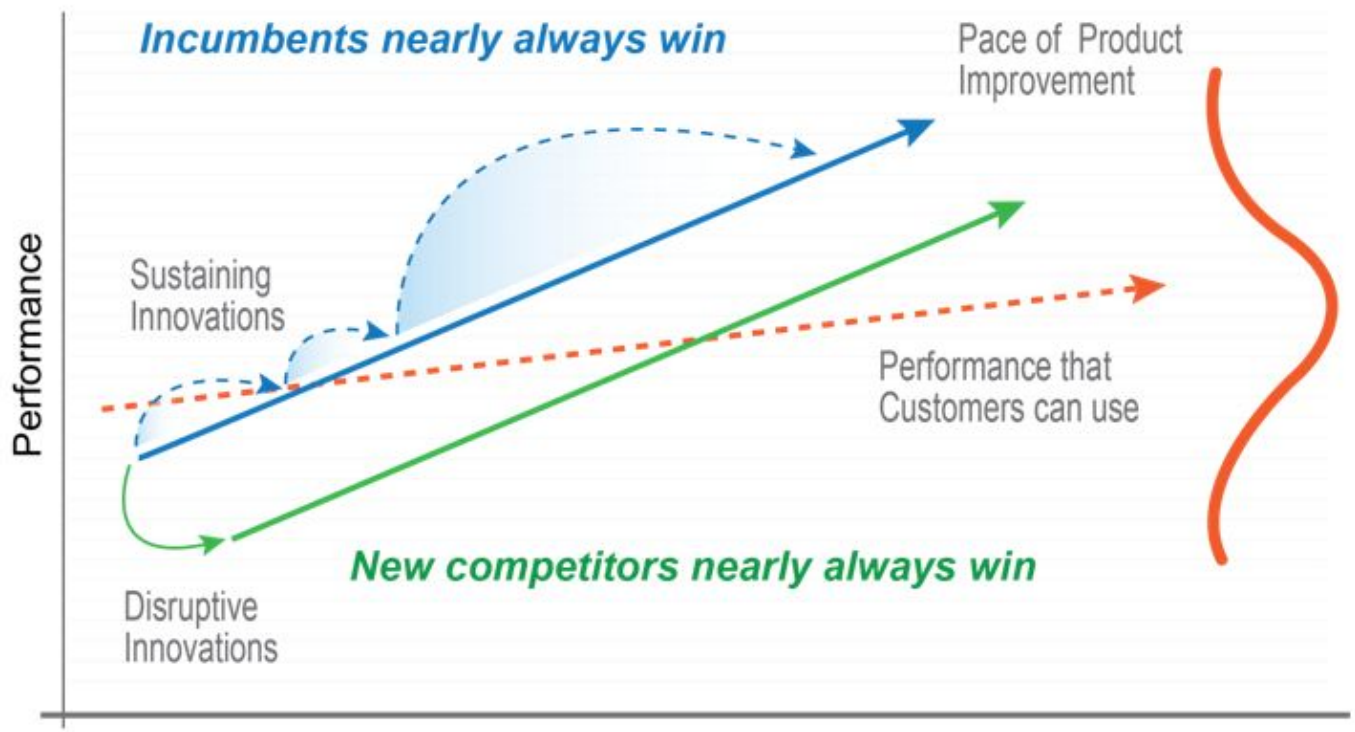

Figure 1. Disruptive Innovation

Source: Christensen (2003)

Market trends indicate that the coming years will witness a storm of both sustaining and disrupting innovations, which will shake and reshape all markets and industries (Hang \& Kohlbacher, 2008; Kim \& Mauborgne, 2005; Paap \& Katz, 2004; Tellis \& Golder, 2003). This in turn will also have a significant impact on global economies and government work in relation to e-government development.

There is a strong relationship between e-government progress and technological developments as we highlighted earlier. E-government is still struggling to move to more advanced levels of development amidst the growing choices of technologies. Although the full transformative upshots of e-government loiter unrealized in principal, the precipitous augmentation in interest and resources dedicated to e-government initiatives is likely to contribute to the development of this cardinal field of practice.

In this article we focus on shedding light on some technological trends that governments need to heed in their e-government initiatives. These trends are expected to have a high disruptive impact on existing e-government service delivery methods, as well as the interactions channels between governments and citizens. The design and content of this article aims to contribute towards providing a helicopter-level view of what policymakers and practitioners need to be paying attention to in terms of conceptual and technological developments in the field of e-government.

This article is structured as follows. Section 2 provides a short overview of the field of e-government. Section 3 outlines five major technological developments and trends that governments need to address in their e-government initiatives. Section 4 stipulates the evolving role of modern identity management infrastructures in enabling identification and authentication methods on smart mobile phones. Section 5 provides a brief discussion and reflection on areas surrounding the implementation and progress of e-government, and the article is concluded in the following section, section 6 .

\section{2. e-Government: A State of Constant Change and Revolution}

According to the World Bank e-government refers to the use, by government agencies, of information technologies (such as Wide Area Networks, the Internet, and mobile computing) that have the ability to transform relations with citizens, businesses, and other arms of government (World Bank, 2011). These technologies can serve a variety of different ends: better delivery of government services to citizens, improved interactions with business and industry, citizen empowerment through access to information, or more efficient government management (World Bank, 2011). Among the many potential contributions include lessening corruption, increased transparency, greater convenience, revenue growth, and/or cost reductions.

There are hundreds of other definitions in the current literature of what e-government means (Andersen \& Henriksen, 2005; Atkinson, 2003; Brown, 2003; CDT, 2002; De, 2004; Devadoss et al., 2002; Grönlund, 2002; Satyanarayana, 2004; Shailendra et al., 2007; UNDESA, 2003). Most definitions in the field of practice take a governance perspective (Grönlund \& Horan, 2004). All in all, e-government globally is viewed to not only to be about 
computerization of a government system or a technology endeavor but a belief in the ability of technology to achieve high levels of improvement in various areas of government (APT, 2012). Accordingly, various models have been developed to implement e-government and leverage IT in facilitating organizational change in government business (Zarei et al., 2008). E-government implementation (or maturity) models primarily use the $\mathrm{X}$ and $\mathrm{Y}$ dimensions of complexity and integration levels to illustrate the development as we move from one phase to another.

Figure 2 depicts one of the early e-government models that consist of four phases. The first phase embodies an early and very basic online presence, where governments start creating websites and use them for informational and very limited interactions with citizens. Phase two involves creating links to archived information that is easily accessible to citizens, as for instance, documents, forms, reports, laws and regulations, and newsletters. In the third phase, governments develop interactive portals that provide online services and aim to enhance online user experience, e.g., downloadable forms for tax payments and applications for license renewals. The fourth phase is where all government transactions are conducted online, and available on a " $24 / 7$ " basis.

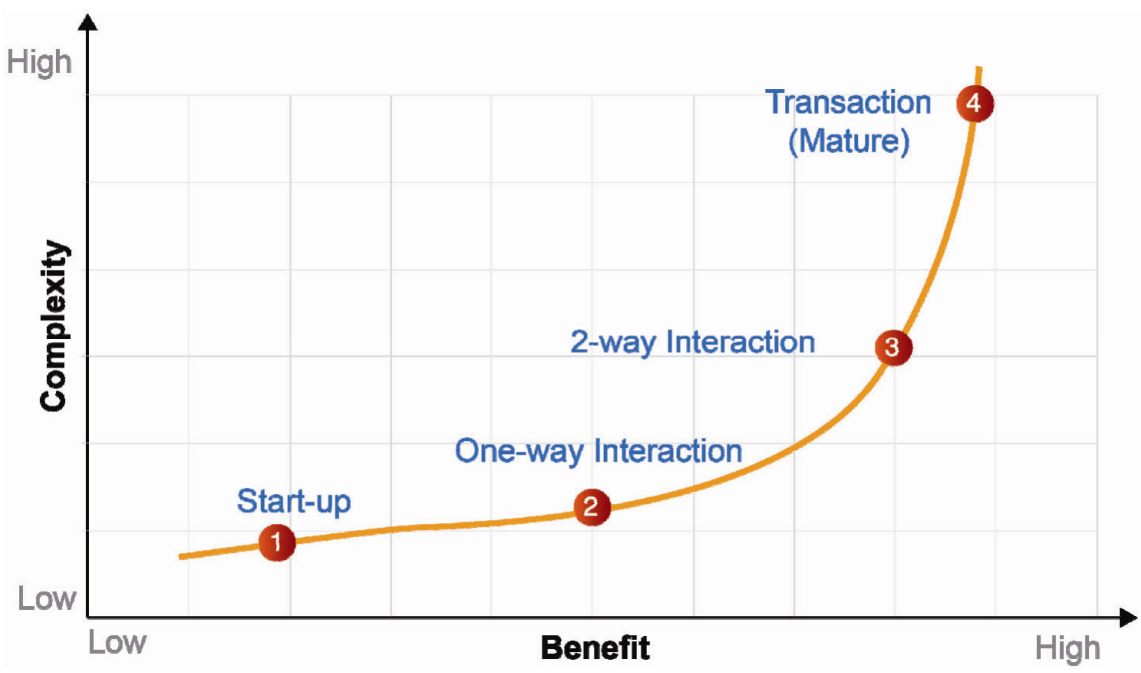

Figure 2. Early e-Government Models

Another model is depicted in Figure 3. It provides a more enhanced view of e-government development stages. Although the first and second phases are similar to the ones in the earlier diagram, the third and fourth phases are a little different in the below diagram. The online services provided in the third phase are limited to a single organization. Services at this stage include not only traditional internet-based services, but are delivered on various electronic channels, some of which might be considered disruptive, like iPad apps for instance. Services in the fourth phase are cross boundaries, and involve concepts like a "one-stop-shop" where some kind of collaboration is needed between government agencies to enable such business models.

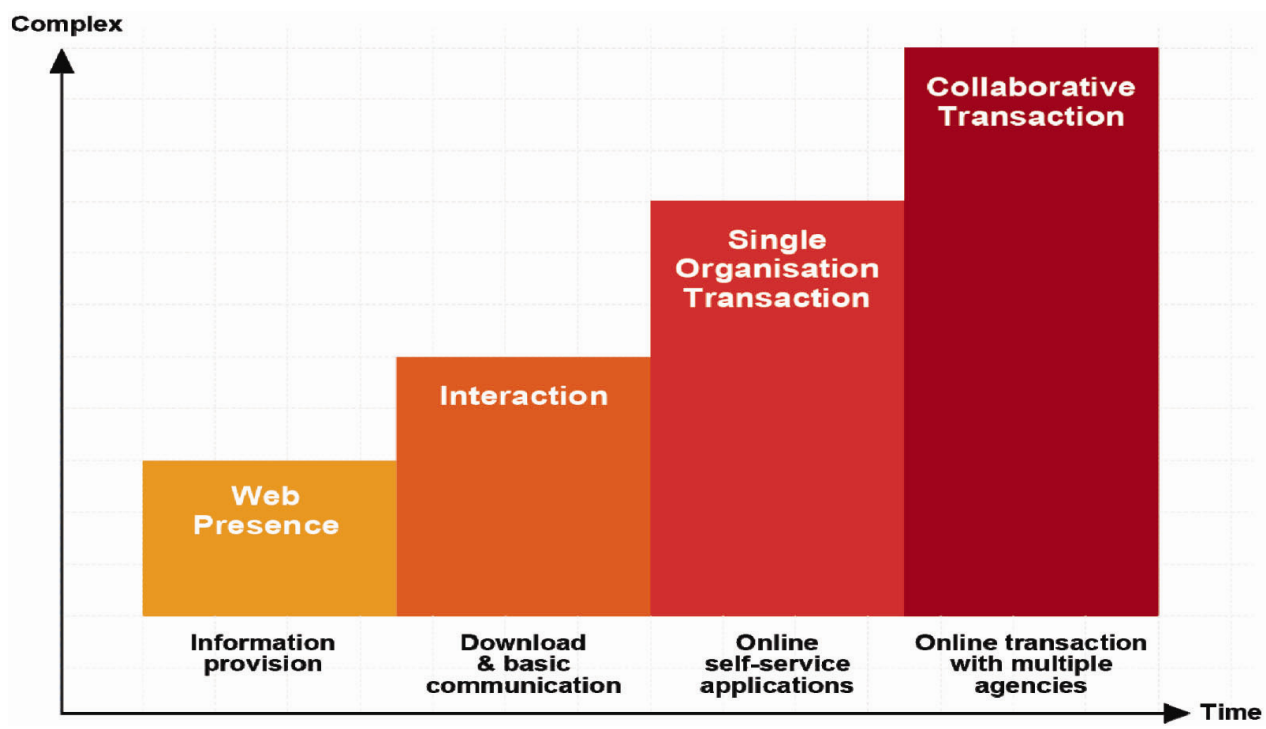

Figure 3. e-Government Evolution to Collaboratively Enable Inter-Agency Transactions 
The third e-Government model is depicted in Figure 4. Compared to the earlier (second) model, this model pushes the transactional phase one step back to phase two, and breaks down the third phase into two new phases. The third phase is where governments initiate the transformation of their processes and services rather than the automation. The focus at this stage is on integration of government functions at different levels, such as those of local governments and central/state governments. The fourth phase focuses on the integration of different functions from separate systems so as to provide citizens with a unified and seamless service and true one-stop-shopping experience (Layne \& Lee, 2001). The authors indicate that the integration of heterogeneous requirements and resolving conflicting system requirements across different functions are typically major stumbling blocks for any government to reach this stage.

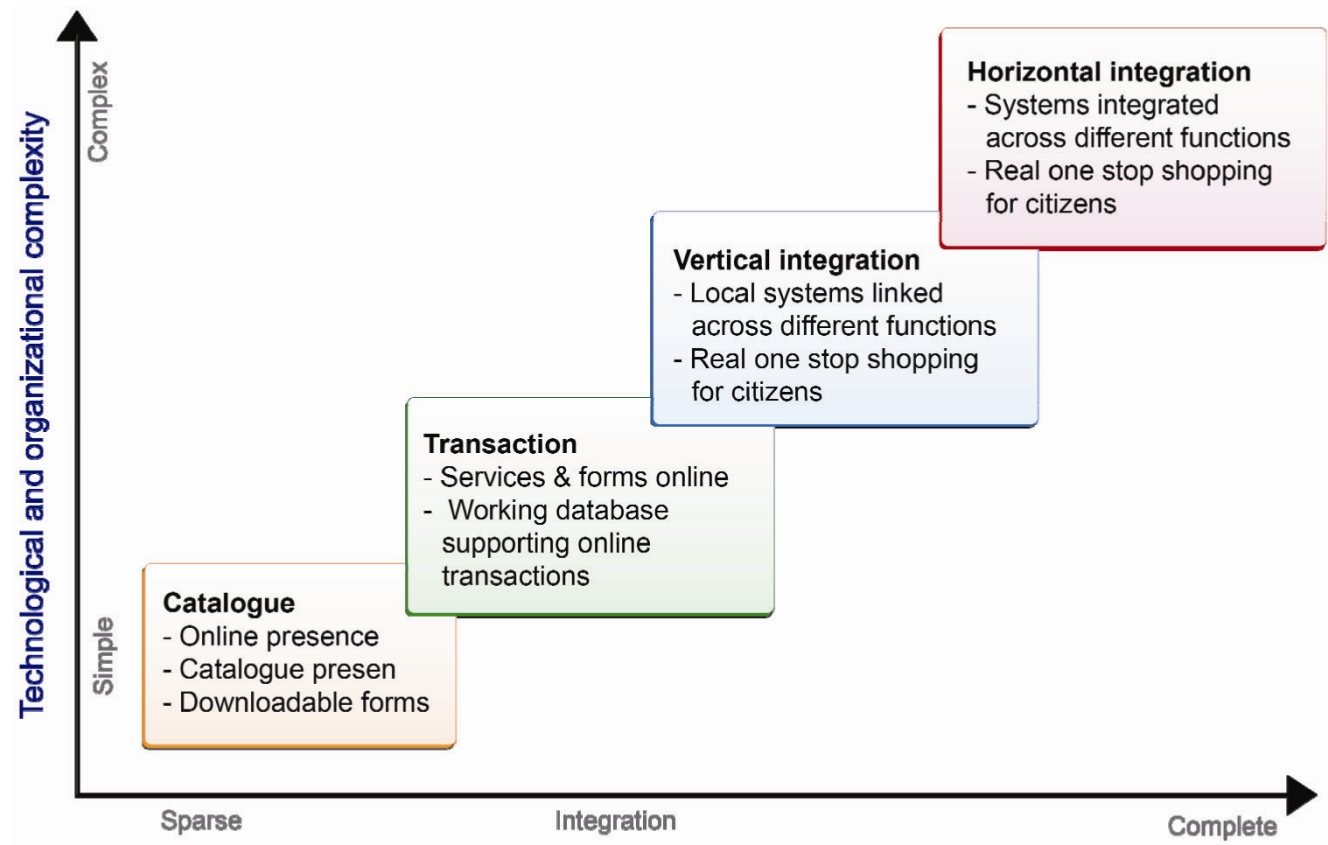

Figure 4. e-Government Evolution to Vertical and Horizontal Integration

Figure 5 depicts other models that specify the level of maturity or development of e-government.

\begin{tabular}{r|l}
\hline Gartner & Publish $\rightarrow$ Interact $\rightarrow$ transact $\rightarrow$ integrate \\
\hline UNDESA & emerging $\rightarrow$ enhanced $\rightarrow$ interactive $\rightarrow$ transactional $\rightarrow$ networked \\
\hline OECD & information $\rightarrow$ interaction $\rightarrow$ transaction $\rightarrow$ and transformation \\
\hline
\end{tabular}

Figure 5. e-Government Maturity Models

Source: Baum and Maio (2000); Field et al. (2003); UNDESA (2003)

From our view point, Layne and Lee's four-stage model (2001) is more applicable to guide current development efforts. Our research and studies in the field indicate that governments have had limited successes in practice (Al-Khouri, 2013; Al-Khouri \& Bal, 2007). There is no real evidence of success stories of true vertical and horizontal integration projects. Nonetheless, many of the announced successes in integration projects are superficial and cannot elevate to enable seamless and real-time transactions.

Various studies also indicate that almost 85 percent of e-government projects are failures (Heeks, 2006; Stanforth, 2010). See also Figure 6. This sounds horrific if we take into consideration the gigantic investments in this field (Gubbins, 2004). Despite this fact, the field of practice and academia did not succeed to present a clear recipe to achieve success and avoid failure, but rather we find hundreds of approaches, frameworks, and methodologies to support successful implementation. 


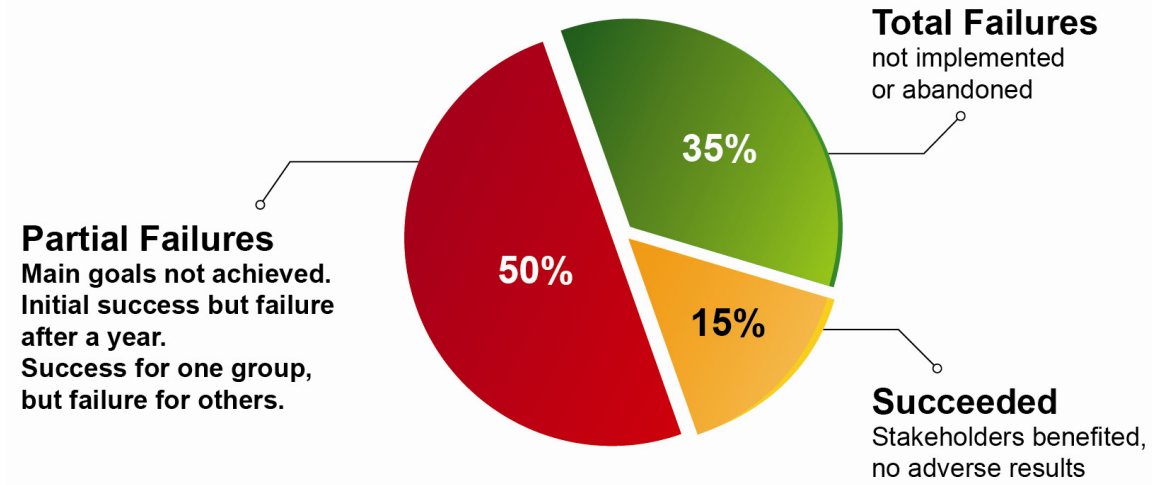

Figure 6. Survey Results of e-Government Implementations

Despite all the work and reasons listed in the existing literature, as practitioners we tend to believe that the evolving nature of technologies is among the many reasons for such stories of failure and the confusion in the field. Let us look at Gartner hype cycles to explain our point here.

The Gartner hype cycle depicted in Figure 7 graphs the visibility and adoption of a technology and its applications over time. Each hype cycle drills down into five key phases of a technology's life cycle: technology trigger, peak of inflated expectations, trough of disillusionment, slope of enlightenment, and plateau of productivity. Table 1 provides an explanation of each hype cycle. Simply put, these stages typically show technology evolution and industry excitement about it. These technologies have two ways of changing: either they disappear as they fail to meet the wild expectations of the industry, or they will evolve further to become more relevant to solving real business problems and present new opportunities. The overhyping and ever increasing technological options put governments in a dilemma of what to choose and what path to follow. See also Figure 7.
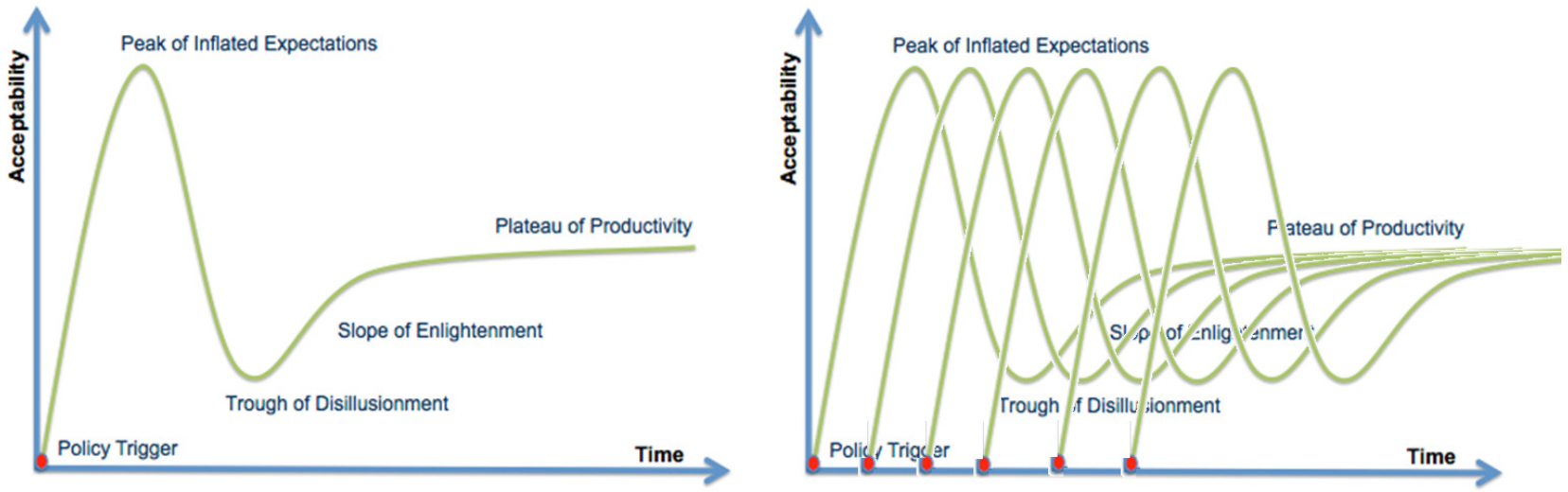

Figure 7. Gartner Hype Cycle

Table 1. Five Phases of a Gartner's Hype Cycle

\begin{tabular}{ll}
\hline Hype Cycle & \multicolumn{1}{c}{ Description } \\
\hline Technology Trigger & $\begin{array}{l}\text { A potential technology breakthrough kicks things off. Early proof-of-concept } \\
\text { stories and media interest trigger significant publicity. Often no usable products } \\
\text { exist and commercial viability is unproven. }\end{array}$ \\
Peak of Inflated & $\begin{array}{l}\text { Early publicity produces a number of success stories, often accompanied by } \\
\text { scores of failures. Some companies take action; many do not. }\end{array}$ \\
$\begin{array}{l}\text { Expectations } \\
\text { Trough of }\end{array}$ & $\begin{array}{l}\text { Interest wanes as experiments and implementation fail to deliver. Producers of } \\
\text { the technology shake out or fail. Investments continue only if the surviving } \\
\text { provillusionment }\end{array}$ \\
Slope of & $\begin{array}{l}\text { Another instance of how the technology can benefit the enterprise starts to } \\
\text { crystallize and becomes more widely understood. Second- and third-generation } \\
\text { products appear from technology providers. More enterprises fund pilots; }\end{array}$ \\
& $\begin{array}{l}\text { conservative companies remain cautious. } \\
\text { Mainstream adoption starts to take off. Criteria for assessing provider viability } \\
\text { Plateau of }\end{array}$ \\
Productivity & relevance clearly defined. The technology's broad market applicability and \\
&
\end{tabular}


The point that we would like to make here is that of the dynamic nature of technological evolution and the somewhat reasonably slow government responsiveness. Governments have been characterized as "big elephants" for a long time. They move slowly, and sometimes their bureaucratic style is controlled by their political nature and context. This makes them the slowest and very last adopters of a given technology hype. Once governments implement a technology, it stays there for long. This is not the case in the private sector, where they tend to sustain and develop such technologies, and plan for incremental breakthroughs. However, despite the excuses we use, disruptive innovations are turning things around. Figure 8 depicts the emerging technologies, some of which are expected to re-shape organizations both in public and private sectors.

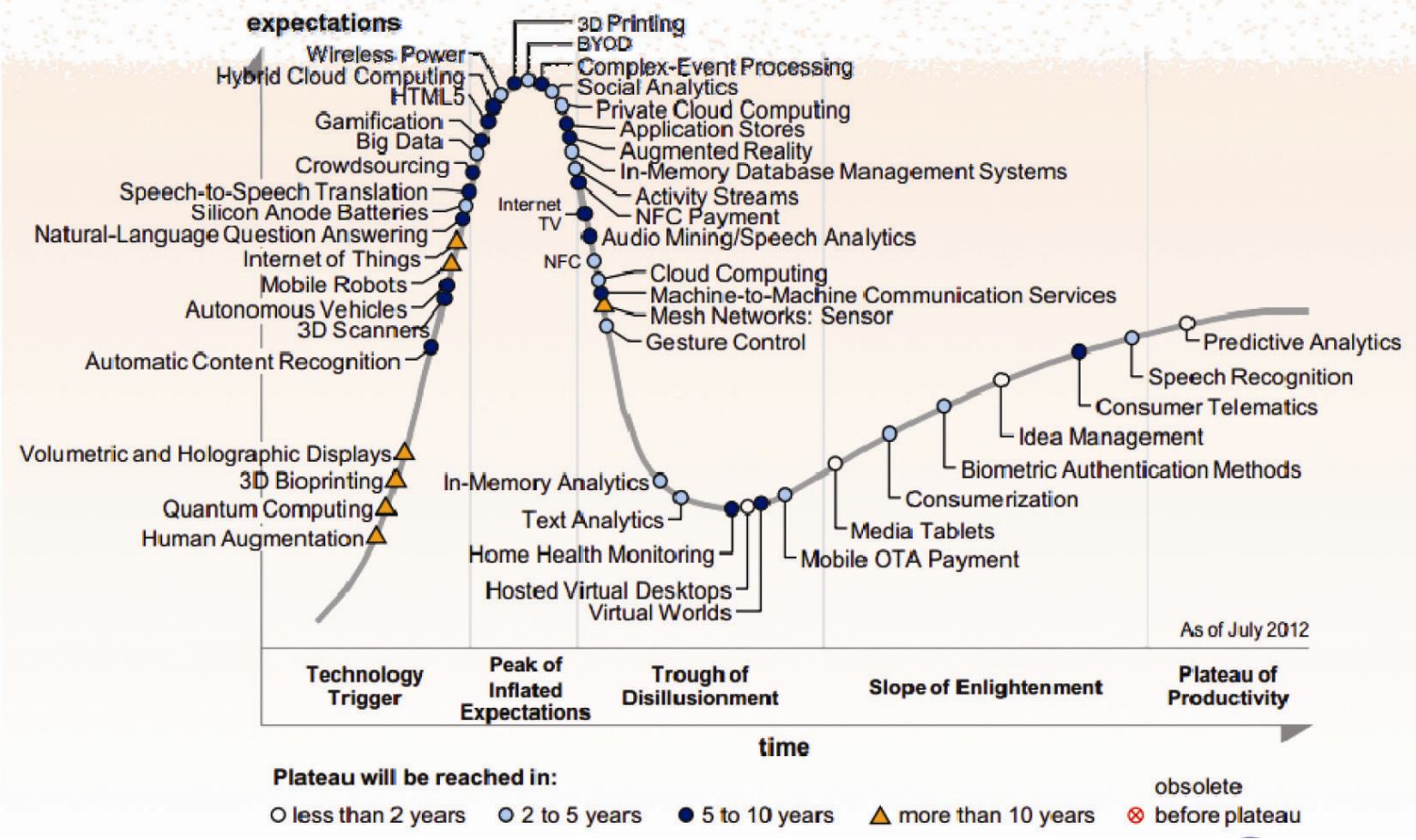

Figure 8. Evolving Technologies According to Gartner Research

From a different standpoint, the decentralized approach of implementation has opened room for diverse interests in dissimilar technologies to be adopted in the government sector. Each organization has its own standpoint and view of sustaining or disruptive innovation adoption. The level of responsiveness varies greatly from one to another government organization. Each government organization may have its own technological implementation and readiness level. The complexity arises when different and silo systems need to talk to each other, but are confronted with a reality that makes this a nightmare. In other words, the integration of systems, be they vertical or horizontal, becomes a moving target because of interoperability, (non)-standardization, and other network effects (Cave and Simmons, 2007).

This is perhaps why e-government is facing difficulty in moving up the development phases of vertical and horizontal integration levels, at least from a technical perspective. Having said that, the next section provides an overview of some critical technological trends that governments need to take into account in their e-government plans. These have considerable implications for practitioners in the field of e-government.

\section{Technology Trends}

Technological developments are driving e-governments to address growing citizens demand for 'better government' in terms of convenience, accessibility, efficiency, effectiveness of government operations. The recently published reports by Deloitte and International Data Corporation (IDC) indicate the need to pay higher attention to five technological hype cycles: social, mobile, analytics, cloud and cyber technologies (Deloitte, 2013; IDC 2013). The reports also indicate that these are likely to converge in the short future and contribute towards having the most significant impact on businesses. These are discussed next subsequently. 


\subsection{Social Business Process Re-engineering}

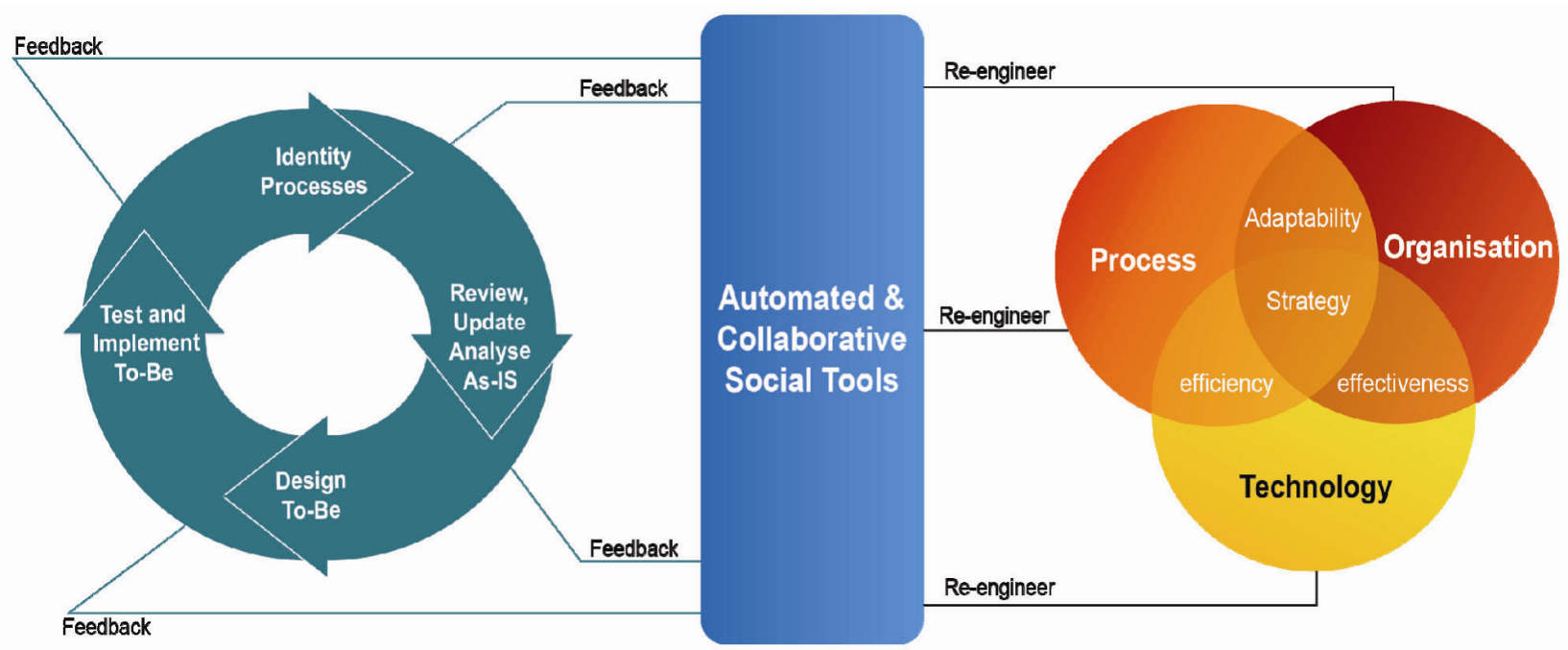

Figure 9. Socially Driven Business Process Reengineering Cycle

The traditional concept of business process re-engineering (BPR) focuses on the analysis and re-design of workflows and processes within an organization (Hammer \& Champy, 1993). Much of the earlier BPR initiatives leveraged information technology to automate manual tasks, and/or to minimize processes in order to attain dramatic improvement in critical performance measures, such as cost, quality, service, and speed. Recent developments in the field of technology are shifting the focus of BPR initiatives to not only aim merely on the optimization of existing processes and applications, but also to the innovation possibilities through the use of social media technologies (Thames, 2011). See also Figure 9.

Social BPR leverages social tools and automation of collaboration to integrate the output of collaborative (human) steps to enhance process output (Thames, 2011). It focuses not only on efficiencies but also on maximizing the value of process output. Social BPR recognizes that the output of business processes can be significantly improved if the process can harness the power of collaborative and conversational activities between parties that have logical input into the process. This is to say that social tools provide new capabilities like capturing, analyzing, and accommodating conversational steps that can be integrated into core business processes. Social reengineering by design is about creating new ways to motivate employees and customers, and reshaping the content and context of work to improve business performance (Ferguson, 2013). It is a course driven by mindshare and engagement with a more enlightened, user-centric approach to problem-solving and knowledge management (Clifford, 2013; Davenport \& Patil, 2013; Raftery, 2013).

Governments need to pay more attention to aspects of social tools to once again re-engineer their processes, systems, and the overall organization. Social platforms can be used to fundamentally change the hierarchal and bureaucratic approaches in government agencies, e.g., how the work gets done, solutions are reached, and innovation is stirred (Bornstein, 2013). The ultimate goal of social re-engineering should be directed towards reducing silos and systematically putting data, people, and processes in the operational contest in communication (Manifesto, 1999). Social collaboration approaches and tools have the potential to play a vital role to support e-government progress. As such, governments need to embark on social-based business processes and re-engineering initiatives to address business improvement opportunities.

\subsection{Mobile Adoption Era}

Mobile government (or m-government, referring to the extension of e-government to mobile platforms) is an important area of practice to improve the productivity of public services and the responsiveness of government (McMillan, 2010). The hi-tech and fast-moving innovation engine in the mobile industry is re-shaping business operating models and marketplaces. Mobile phones and smart devices are spreading ubiquitously as portable mini computers across the planet (Perez, 2012). Global mobile penetration grew ten-fold in the last 10 years and is likely to reach almost $100 \%$ by 2018 (Rannu, 2010).

A study by Morgan Stanley reports that by 2014, internet access through handheld devices will surpass laptops and desktops (Meeker, 2010). See also Figure 10. Forbes points out that smartphones and tablets are progressively 
becoming the "remote control" of the world (Olson, 2013). The following two sections will outline two trends of mobility that are considered to be adding significant value to e-government services.

\section{Global Mobile vs. Desktop Internet user Projection, 2007 - 2015}

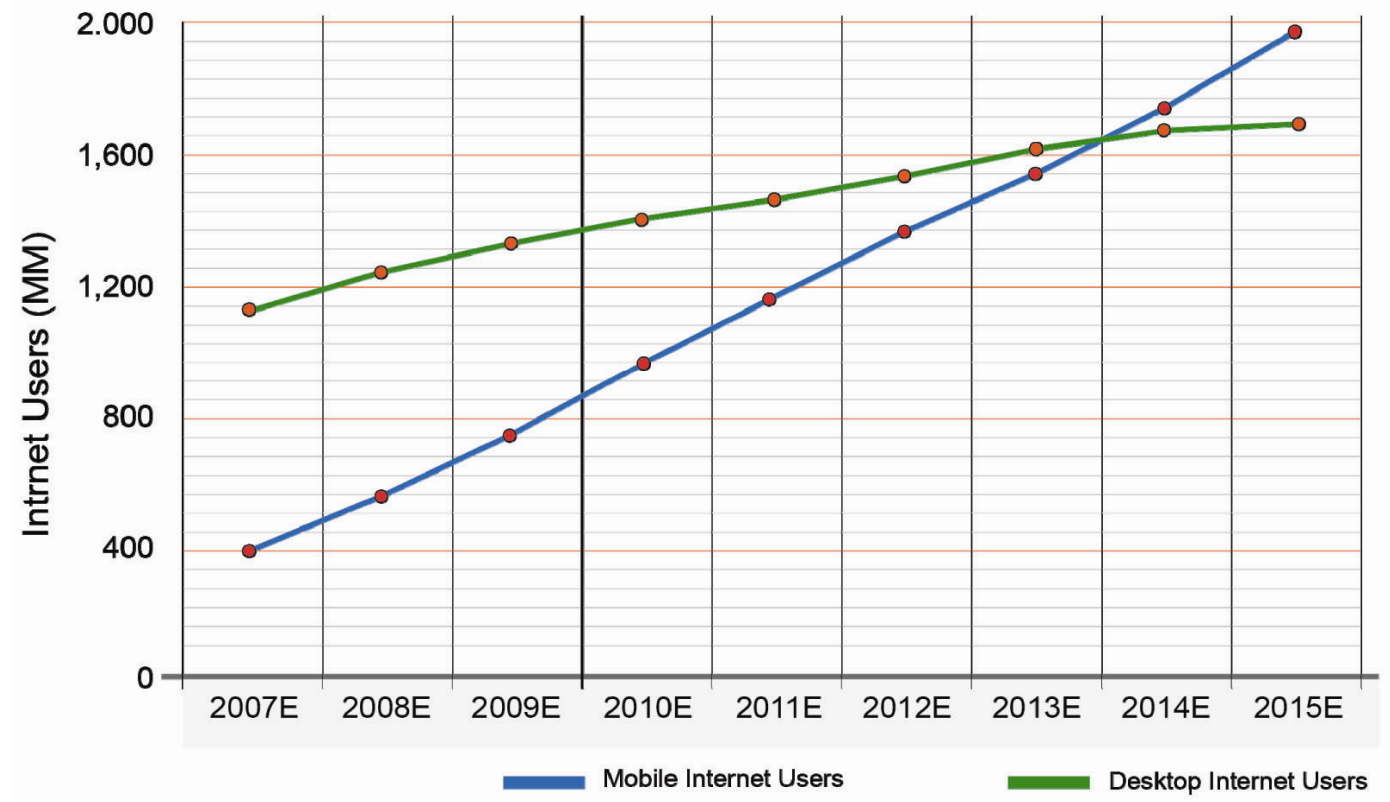

Figure 10. Mobile and Desktop Internet Users

Source: Meeker (2010)

\subsubsection{Mobile Applications (mobile apps)}

Mobile applications (mobile apps). Mobile application (or mobile app) is a software application designed to run on smartphones, tablet computers, and other mobile devices. The term app is becoming popular as its usage has become increasingly prevalent across mobile phone users (Ludwig, 2012). Market research shows an increase in mobile app adoption in recent years (Hughan, 2013; Ludwig, 2012). It is estimated that 1.2 billion people worldwide were using mobile apps at the end of 2012 and this number is forecasted to grow to 4.4 billion users by 2017 (Whitfield, 2013). See also Table 2.

Table 2. Users of Mobile Apps Worldwide by Region, 2012-2017

\begin{tabular}{lccc}
\hline Region & 2012 & 2013 & 2017 \\
\hline App users worldwide & 1.2 billion & N/A & 4.4 billion \\
Asia Pacific & $30 \%$ & $32 \%$ & $47 \%$ \\
Europe & $29 \%$ & $28 \%$ & $21 \%$ \\
North America & $18 \%$ & $17 \%$ & $10 \%$ \\
Middle East \& Africa & $14 \%$ & $13 \%$ & $12 \%$ \\
Latin America & $9 \%$ & $10 \%$ & $10 \%$ \\
\hline
\end{tabular}

Source: Whitfield (2013)

There are serious implications for governments and businesses in this domain. Mobile apps allow the leverage of nearly infinite resources of information and services. It is important to consider mobile apps as a central part of the e-government strategy to benefit from the opportunity of engaging new, constantly connected citizens. Governments could leverage the growing network of mobile citizens to improve the delivery of convenient and highly efficient public services (Su et al., 2010). In Australia, the share of citizens using mobile devices to interact with government doubled in just two years, with 35\% of them using a mobile app at least monthly (Grandy \& Newman, 2013). Mobile devices are the today's "killer" solutions for e-government to connect with those who were left behind in the digital gap. 


\subsubsection{BYOD and CYOD}

In enterprise terms, concepts like bring your own device (BYOD) and choose your own device (CYOD) are prompting changes in the patterns in enterprise application development (Hayes \& Kotwica, 2013). BYOD is where people can bring their own personal devices such as laptops, tablets, and smart phones to access corporate networks and data. CYOD is where employees choose from a pre-approved list of devices, owned by the company, but can be used from anywhere. Both concepts are viewed to enable organizations to take advantage of new technology faster, and have the potential to reduce traditional hardware costs and improve organizational productivity and flexibility (Azoff, 2013). Despite the security concerns, it is indicated that it would be nearly impossible to prevent BYOD from occurring, and that the only option is to try to manage the risks posed by it (Barbier et al., 2012; Drury \& Absalom, 2013; Wiech, 2013).

Solutions like mobile device management (MDM) address much of the concerns related to data security, policy, and integration (Redman et al., 2011). MDM solutions allow agencies to have much tighter control on how smartphones and tablets are used to conduct official business (Klett \& Kersten, 2012). Most MDM solutions prevent unauthorized devices from accessing a network, allow phones to be remotely disabled, and can be used to deploy enterprise applications (Johnson, 2011).

Once again, governments need to take advantage of mobility and develop a phased approach to build an ecosystem that supports BYOD plans. Government employees, similar to their colleagues in other sectors, will continue to add devices to the corporate network to make their jobs more efficient and enjoyable. Therefore, organizations must plan for this legally, operationally, and culturally (Symantec, 2012).

We strongly believe that more government agencies will start implementing policies for dealing with both corporate-owned and personally-owned devices to address needs of workers for reliable access from anywhere at any time, who can stay connected and productive outside normal business hours (see also Abdul, 2013). Figure 11 depicts the results of a survey conducted by Aruba Network in 2012 that revealed growing interest in the development and implementation of the BYOD phenomenon in private and public sector organizations across Europe, the Middle-East, and Africa (EMEA). The study indicated that organizations are taking considerable steps towards BYOD adoption. Of those organizations polled, $69 \%$ allowed some form of BYOD, ranging from strictly limited to internet connectivity, to some access to corporate applications on employee-owned devices. In short, BYOD is not an option to ignore.

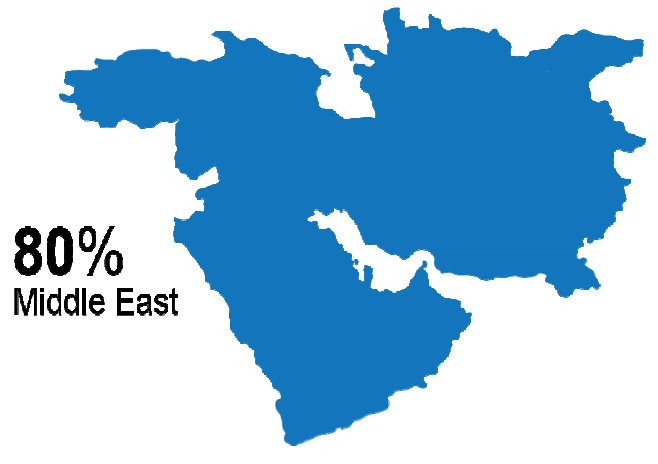

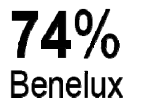

$$
\text { Benelux }
$$

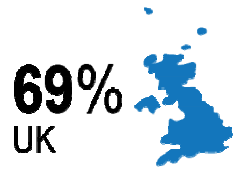

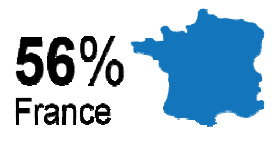

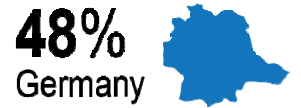

Figure 11. Growing Interest in BYOD Across EMEA Countries

\subsection{Cloud Computing}

Cloud computing appears to be a transformative change and a revolutionary concept for many businesses, governments, and citizens (Collier, 2012). Cloud computing is "a model for enabling ubiquitous, convenient, on demand network access to a shared pool of configurable computing resources (e.g., networks, servers, storage, applications, and services) that can be rapidly provisioned and released with minimal management effort or service provider interaction" (NIST, 2010). The concept itself has a huge impact on cost savings, operations improvements, 
and scalability (Erl et al., 2013). According to Gather, by 2012, 20\% of businesses have adopted cloud services and owned no IT assets (Veljanovska \& Zdravevska, 2013).

Cloud computing emphasizes a shift from stand-alone legacy systems to integrated public and private cloud computing solutions. Tables 3 provides the service models enabled by cloud computing.

Table 3. Cloud Computing Service Models

\begin{tabular}{ll}
\hline Cloud Service & Description \\
\hline $\begin{array}{l}\text { Infrastructure as a Service } \\
\text { (IaaS) }\end{array}$ & $\begin{array}{l}\text { IaaS provides the consumer with the capability for provision } \\
\text { processing, storage, networks, and other fundamental computing } \\
\text { resources, and allows the consumer to deploy and run arbitrary } \\
\text { software, which can include operating systems and applications. }\end{array}$ \\
Platform as a Service (PaaS) & $\begin{array}{l}\text { PaaS provides the consumer with the capability to deploy } \\
\text { consumer-created or acquired applications, which are produced } \\
\text { using programming languages and tools supported by the provider, } \\
\text { onto the cloud infrastructure. }\end{array}$ \\
Software as a Service & $\begin{array}{l}\text { SaaS provides the consumer with the capability to use the provider's } \\
\text { applications, running on a cloud infrastructure. The applications are } \\
\text { (SaaS) }\end{array}$ \\
accessible from various client devices, through a thin client \\
interface, such as a web browser (e.g., web-based email).
\end{tabular}

Source: Simić et al. (2012)

In e-government terms, cloud provides a solid foundation for the introduction of widespread provision of services to various stakeholders (Simić et al., 2012). Applications designed using the principles of service-oriented architecture and deployed in cloud architectures will help governments to reduce operational costs and radically scale the delivery of services (Simić et al., 2012). Cloud architectures is argued to have the potential to accelerate the adoption and use of e-government and e-services (Mukherjee \& Sahoo, 2010; Naseem, 2012; Veljanovska \& Zdravevska, 2013).

Migration towards cloud-based services is becoming an option which must be implemented. It is becoming more viable as citizens demand more timely and cost effective e-government services. The "cloud of public services" should be viewed by governments as a catalyst for e-government development, and as a means to attain higher levels of productivity and innovation.

\subsection{Big Data}

With the ever increasing and explosive amount of data in today's world, the ability to analyze large data sets has the potential to fuel new waves of productivity, growth, innovation, and have a dramatic impact on the economy, scientific field, and society at large (Mayer-Schonberger \& Cukier, 2013). The term big data has come to refer to these very large datasets. It also refers to the analytical capabilities to process and gain deeper insights from such datasets. The concept is not new, but the terminology of big data and its modern definition are relatively novel.

According to research conducted by McKinsey Global Institute, big data has the potential to generate substantial annual value in various sectors: $\$ 300$ billion to U.S. health care, $€ 250$ billion to Europe's public sector administration, and $\$ 600$ billion in consumer surplus from using personal location data globally (Manyika et al., 2011). Big data emphasizes a shift from basic analytics to sophisticated visualization, where attention is given to pattern discovery to making real meaning and value. The emphasis is on enabling data-driven decision-making, which should in turn enable faster speed to value, and should have a positive impact on the public sector (Simon, 2013; Yiu, 2012).

In e-government terms, big data analysis presents enormous opportunities for governments to improve the way in which services are delivered to citizens and to businesses, and to make better, targeted use of the limited resources governments have today (Bender, 2013). Research suggests that big data strategies are "the defining element to unlocking the potential" of growing mountains of information and overcoming the diverse challenges (Konkel, 2003). Figure 12 depicts some of the major challenges associated with big data, as per a survey conducted by the Government Business Council in 2013. The challenges reported in the survey included a lack of adequate resources (61\%), lack of data visibility (55\%), misaligned budget priorities $(50 \%)$, and technological barriers to accessing data (49\%). 


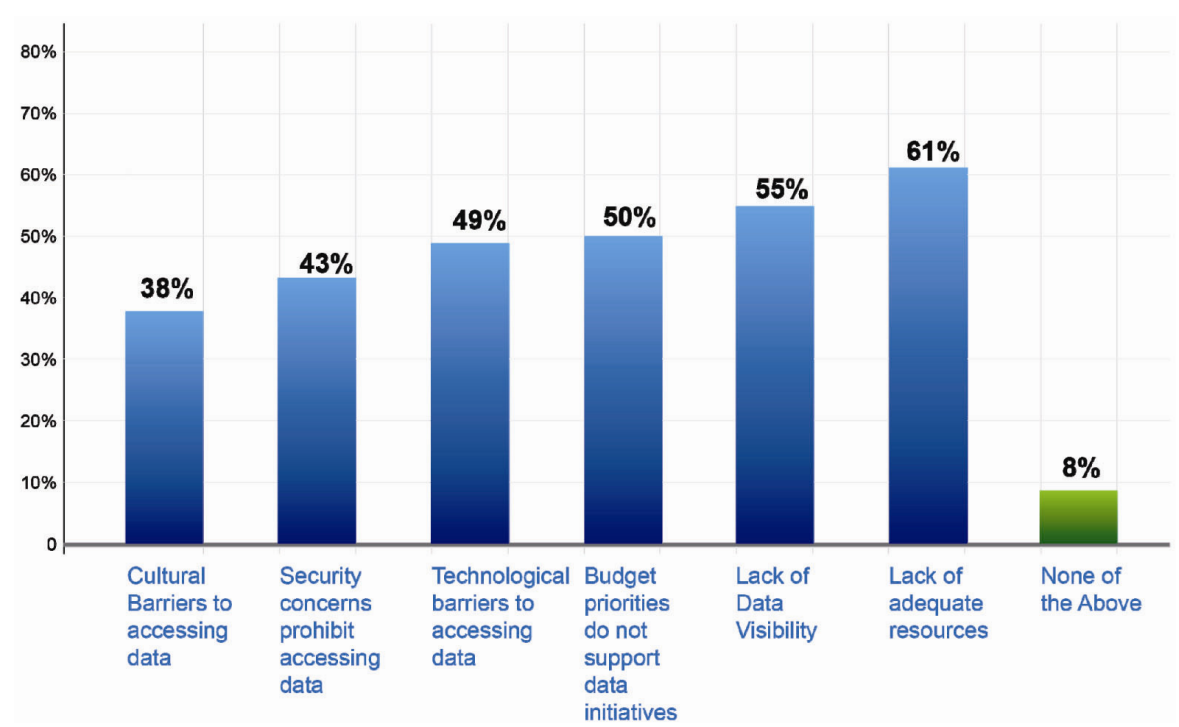

Source: Government Business Council (2013)

Figure 12. Challenges Associated with Big Data

From an e-government perspective, big data can play a critical role in paving the way for more focused and evidence-based policy design and service implementation (Archer, 2003). However, there is a clear need for a big data strategy to enhance cross-agency data analytic capability (Cattie \& Riper, 2013). Big data strategies should be designed to enable governments to build knowledge and generate growth. Strategy initiatives need to focus on (1) delivering more personalized public services that are tailored to meet citizens' needs and preferences, and (2) improved productivity as resources can be directed towards projects with greater confidence of the outcome.

Big data promises to bring fundamental change to government work. Governments need to capitalize on the power of big data to generate insights for capitalizing on new opportunities to transform government and society itself, a similar objective of what e-government attempts to achieve.

\subsection{Cyberspace: The Issue of Security and Privacy}

Communication is one of the foremost mediums that has unquestionably been influenced by the invention of the Internet. Without a doubt, earlier outlined technologies will use the Internet as a platform for communication.

It is critical to that for technological trends outlined in this article to evolve, security and privacy must remain the largest issues today in the cyber world (Ponemon, 2012). The notion that "as long as you are connected, that connection can go both ways" has its own psychological impact on the progress of e-government, and public acceptance and participation.

A study developed by Norton in 2013 revealed that the annual cost of cybercrime exceeded $\$ 388$ billion (Norton, 2013). See also Figure 13. More than 556 million people from 24 countries were victimized by cybercrime according to the same study. Emerging technologies including mobile and cloud computing that have recently insinuated into corporate spheres, blending personal and professional communication, were reported to have opened up new security impacts (Detica, 2011).

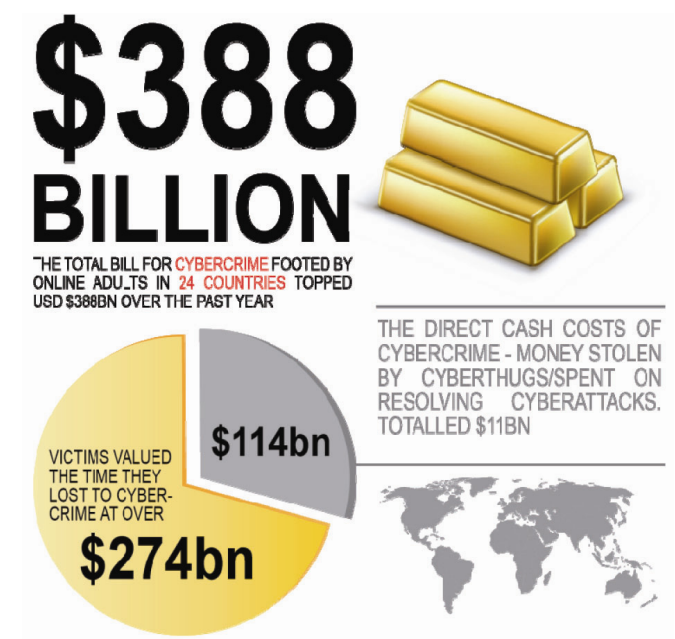

Figure 13. Cybercrime Source: Norton (2012) 
As more and more devices and technologies are getting ubiquitously connected and widespread, threats against nations' critical infrastructures are mounting too. Establishing trust is therefore critical not only for the development of e-government, but also for the successful convergence and evolution of the earlier-outlined four forces.

Trust is defined as "confidence in or reliance on some quality or attribute of a person or thing, or the truth in a statement" (Furman, 2009). In an earlier study that we have conducted, we found that establishing trust and security in online environments were among the primary reported impediments to e-government development (Al-Khouri \& $\mathrm{Bal}$, 2007). It is widely argued that building trust is a gateway for new service paradigms to emerge, thereby developing passive citizen participation into active citizen participation in public service delivery (van Duivenboden, 2002).

Commercially, there are hundreds of products and solutions that are designed to optimize trust, and are widely used in private sector. However, in the e-government context, trust is more talked about but less practiced. Trust is envisaged to be very much associated with the ability to develop a robust identity management system to identify and authenticate individual identities in physical and virtual environments.

Establishing trust through advanced identity management is considered fundamental to unleash the opportunities posed by the technological trends outlined in this article or any other ones. The next section will shed light on some government practices worldwide.

\section{National Identity Management Infrastructure}

Many governments around the world have initiated advanced identity management infrastructures to support citizen identification and authentication needs (Al-Khouri, 2012). Some of the advanced programs produce secure IDs to encourage users to be engaged more actively and more expansively in the digital world (Al-Khouri, 2012b). For instance, countries like Estonia, Belgium, and UAE create digital identity profiles for their citizens, packaged in a secure smart card. This provides advanced capabilities such as those presented in Figure 14.

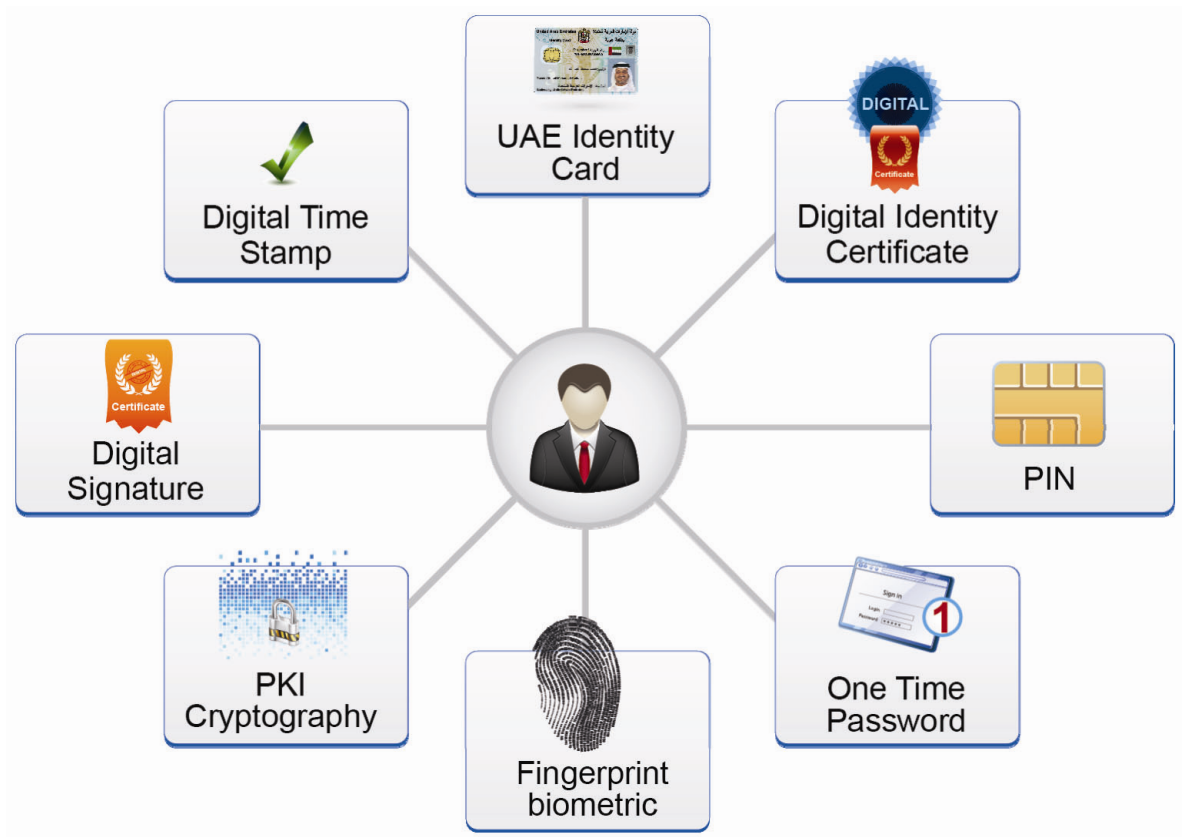

Figure 14. Modern Smart Identity Card Capabilities

Modern identity cards are designed to provide multi-factor authentication capabilities. This should in turn provide higher levels of protection to individuals' security and privacy needs. With such infrastructure, e-government service providers are given verification and authentication services to enable secure remote transactions. Service seekers would remain anonymous on the Web, as only digital certificates or biometrics would be used to establish credential verification. Interestingly, some countries have already started extending their identity management infrastructures to include initiatives related to mobile identity.

Currently, Finland, South Korea, and Singapore are known to have m-enabled government services. They also use NFC (Note 1) technology for transactions on mobile devices (generally for m-wallet). Oman is trying to implement this and Saudi Arabia and Qatar are in the planning stages. The United States, the United Kingdom, France, and 
Germany have e-commerce transactions using NFC in the retail industry to enable m-payments.

However, NFC-based authentication has not been used by anyone so far-especially in conjunction with a national ID. The issue has been that most of the countries that have implemented NFC-based mobile transactions have not used any national ID system and are instead driven by commercial needs. The UAE government has recently started taking a lead in this particular domain.

UAE is currently working to enable all its government services through mobile and smart devices by 2015 (Al-Khouri, 2012). It is trialing NFC-enabled authentication methods based on its national identity card to support the transformation process. The UAE has just enrolled all its legal residents and citizen population and issued them with smart identity biometric and PKI-based cards.

The UAE smart card is a hybrid card with contact and contactless features. The contactless feature enables NFC capabilities and allows smart phones to communicate securely with the national ID card. The rollout of the mobile ID authentication using the national ID card is planned in three phases:

1. A mobile ID application that is downloadable from an online portal.

2. A SIM-loadable mobile ID applet with the mobile PKI.

3. Using the PKI credentials in the ID card for authentication on the mobile devices.

The UAE implementation provides a highly secure ID management and user and device authentication mechanisms in mobile transactions. Figure 14 depicts a high level framework which shows how the NFC solution will be implemented.

The next section will provide a short discussion and reflection on areas surrounding the implementation and progress of e-government.

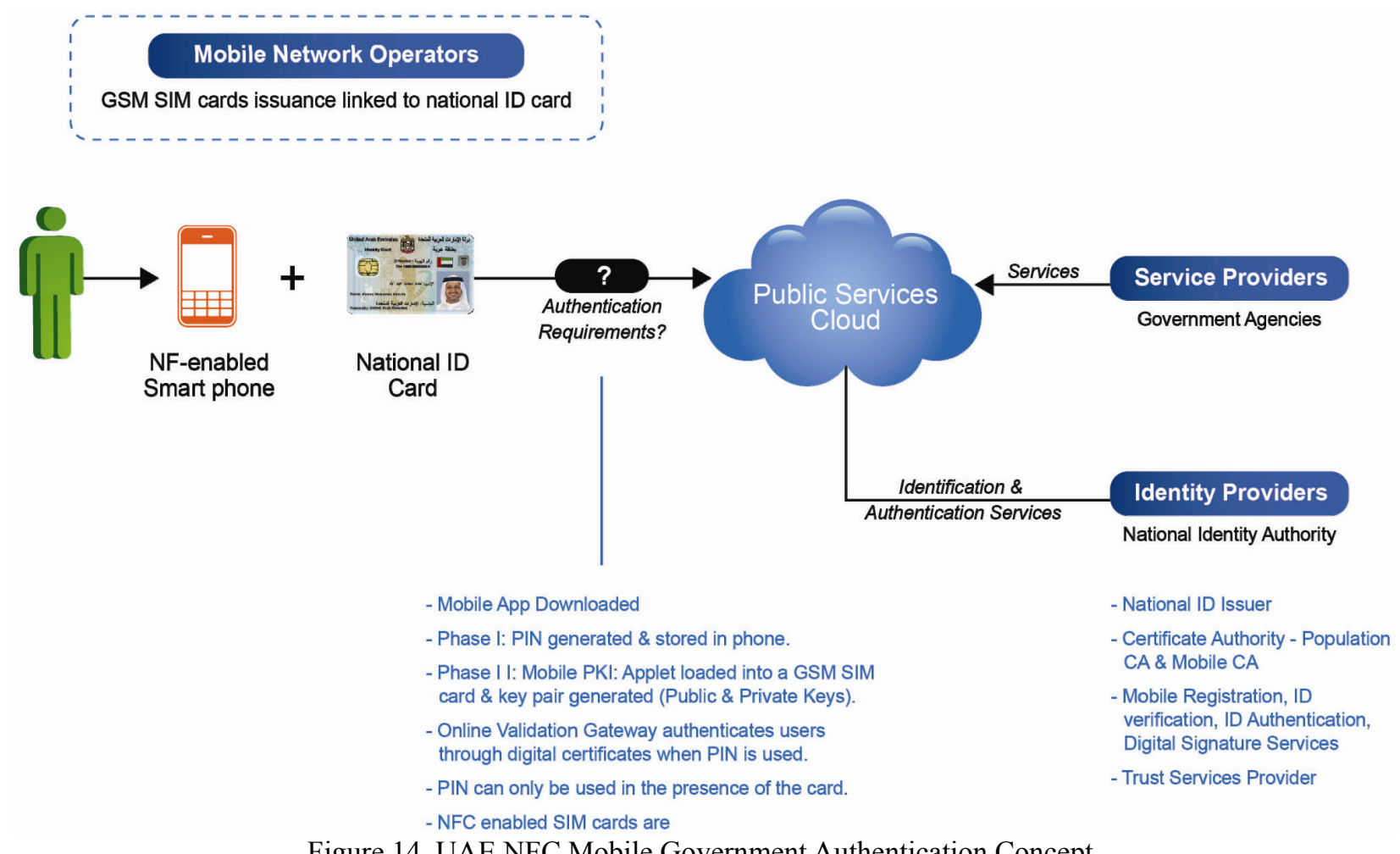

Figure 14. UAE NFC Mobile Government Authentication Concept

\section{Reflection}

The outlined technological developments are important matters for policymakers and practitioners in the field of e-government. Social media have empowered citizens in ways never seen before, increasing the influence that customers can bring to bear on important issues (Thys \& Lacourt, 2013). Electronic transactions and services are also subject to this unforgiving scrutiny, so getting it right is vital (Thys \& Lacourt, 2013). Mobile technologies will indeed change the way governments deliver services. Government practices and trials of NFC technologies in service delivery are likely to promote new innovations. Modern identity management systems have the potential to play a 
key role in enabling delivery of services over smart mobile phones. The case of the UAE is likely to solve the endemic problem of identity in the mobile domain. We would expect more governments to follow suit and implement similar projects.

However, it is important that we do not mix up technological developments and the role of e-government. Indeed, technologies will continue to evolve at a faster pace than what can be practiced in government domains. Practitioners should not look at e-government from a purely technical window. E-government should be viewed as being about citizen well-being and prosperity. There are two points that are critical to comprehend in this regard. These are related to the concepts of citizen centricity and the approach of e-government implementation, which are discussed in the following two sub-sections.

\subsection{Citizen Centricity}

E-Government should be an electronic representation of the conventional government service delivery system. Besides, all governance systems and processes should be reflected in the e-government systems as in normal government processes. Yet, for e-government to succeed, it is essential that the identity of service-seekers and beneficiaries be protected and that trust in transactions be established securely. See also Figure 15. Without this, e-government initiatives will face challenging times to progress forward.

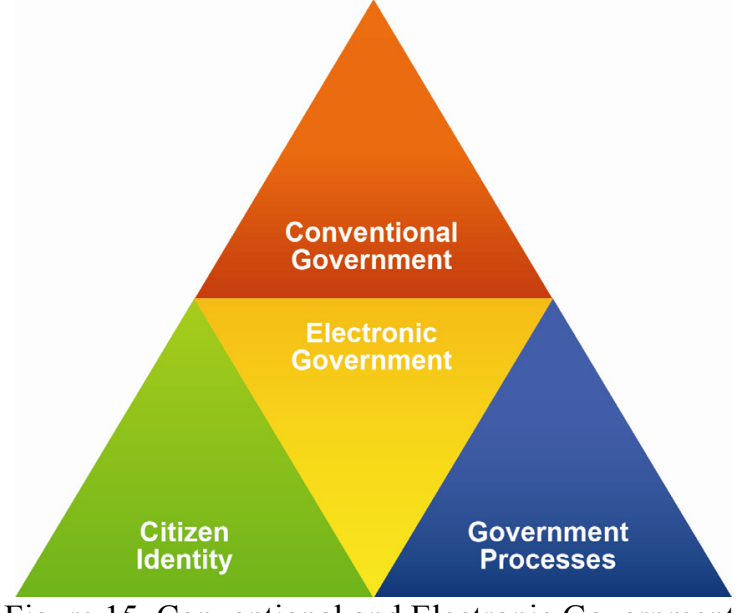

Figure 15. Conventional and Electronic Government

It is also critical to comprehend the evolving government structures, where citizens should come at the heart of the design when e-government is constructed. The historic focus on technology has overshadowed the organizational, structural, and cultural changes needed in the public sector (OECD, 2009). Citizen-centric service involves designing of services from citizens' point of view rather than of the government agencies. See also Figure 16.

The traditional bureaucratic silo systems approach would not support such endeavors (Chakravarti \& Venugopal, 2008). User centricity is not simply about facilitating interactions and making processes and information more accessible to citizens; it is more about an alignment of government work with citizen needs to create economic and social public welfare.
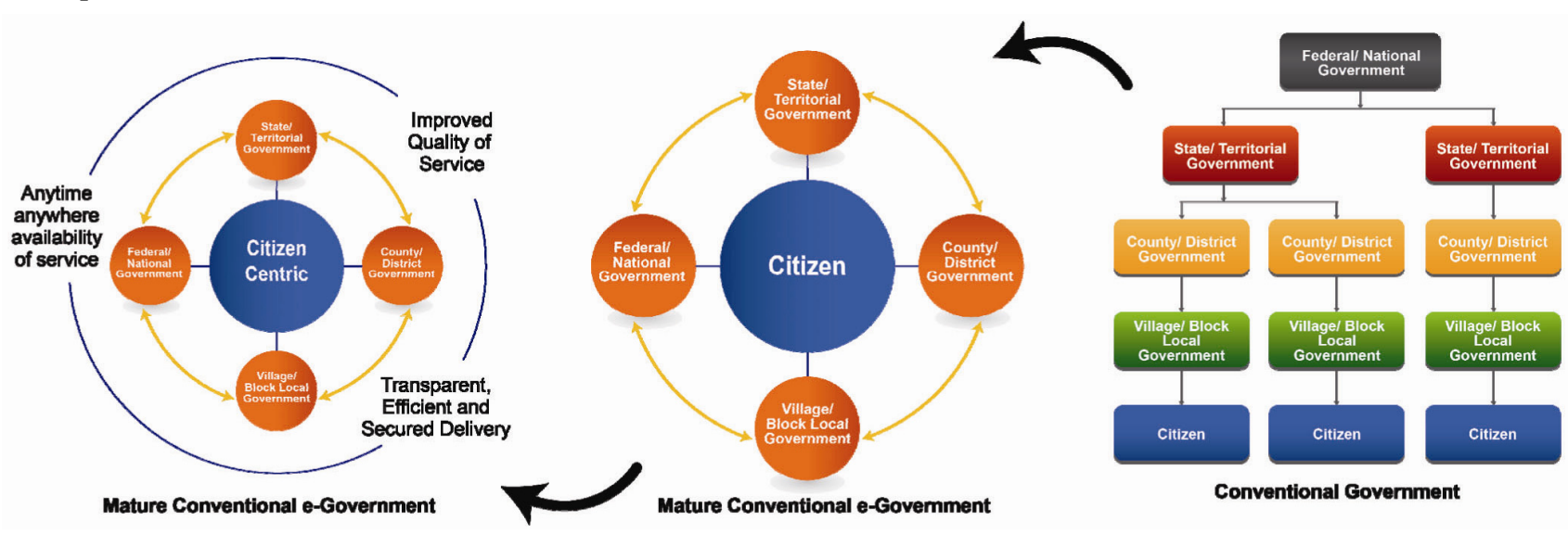

Figure 16. Evolving Government Structures 


\subsection{Centralized vs. De-Centralized e-Government}

Another point here is related to the notion of a centralized e-government or a decentralized approach. We tend to subscribe to the notion of a centralized e-government authority that should direct and implement an e-government model for a country to achieve a good level of success. If we examine the nature of governments and the government models themselves, we see that they are decentralized in nature.

A government is built on the blocks of a local self-government where governance at its grassroots levels is the village or small community. The different forms of government (democratic, monarchy, dictatorial, communist, etc.) are then at a federal or a central level. Any policy or regulation is from the center, and the implementation is local.

This thus presents a strong case for a central e-government authority. When government itself is central in nature, why are we attempting to create e-government in a decentralized way, where planning, regulation, and implementation are all decentralized? This comes across as rather oxymoronic and self-contradicting. This leads us to believe that it is one of the major reasons for the failure of e-governments in many countries.

Heeks $(2002,2003,2006)$ presented an e-government failure model as a design-reality gap using seven factors (ITPOSMO: information, technology, processes, objectives, staffing, management systems, and other resources). This is probably the only scientific work done in this domain, but it looks at the e-government failure purely from an implementation perspective. See also Figure 17.

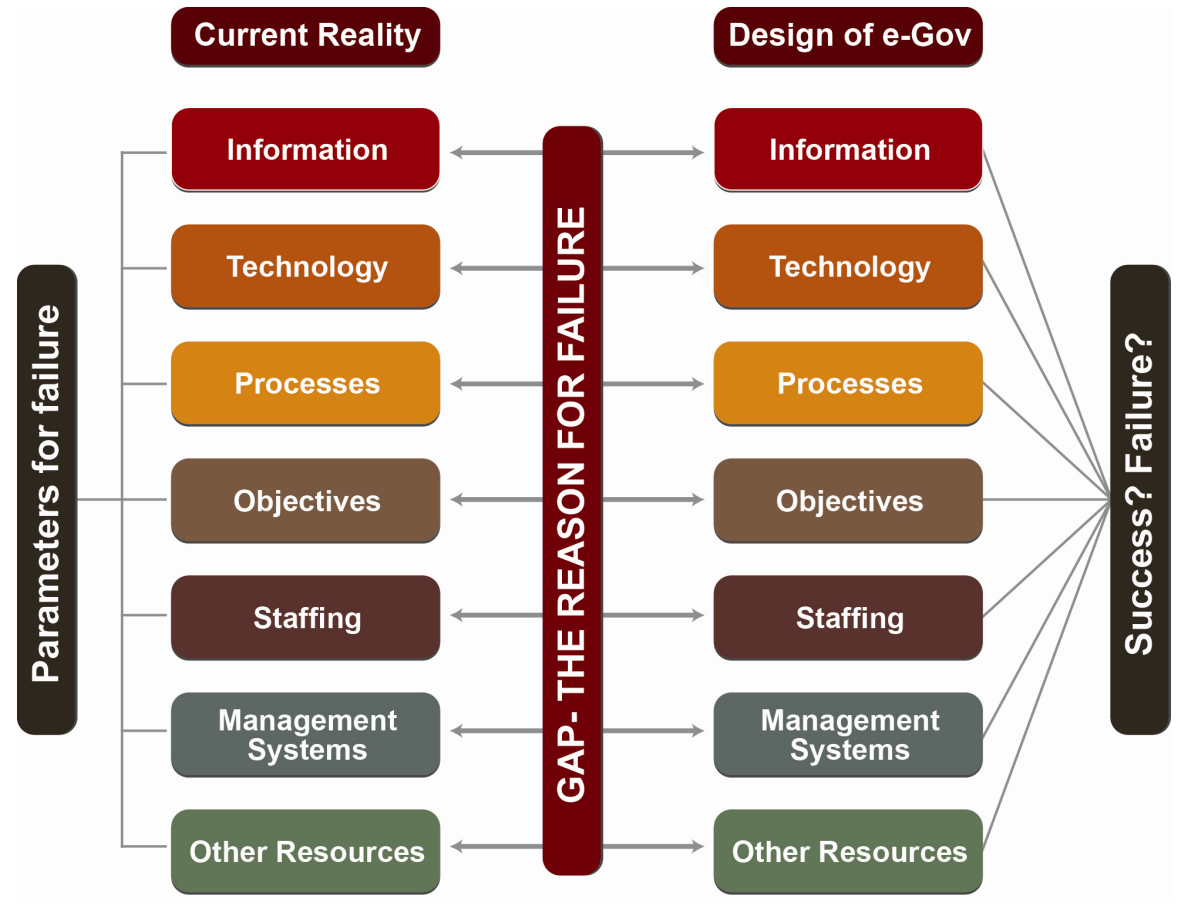

Source: Heeks (2006)

Figure 17. e-Government Failure Model

While this model is still valid at the implementation level, it does not seem to address the hierarchy of the government and government structure. A central e-government entity (similar to the central government) does seem to be a very good solution. This entity would design the e-government, implying policymaking, regulation, standardizing, and more importantly be responsible for compliance. Thus, this entity would define the meta-processes and meta-services for e-government, much like the central government.

This would be the blueprint for the country and thus this central entity would manage the gap that is presented in Heeks model in ensuring that e-government implementation is taken to the grassroots of governance where the citizen is the focus. Thus the much-touted citizen inclusion and empowerment becomes a reality. See also Figure 18. 


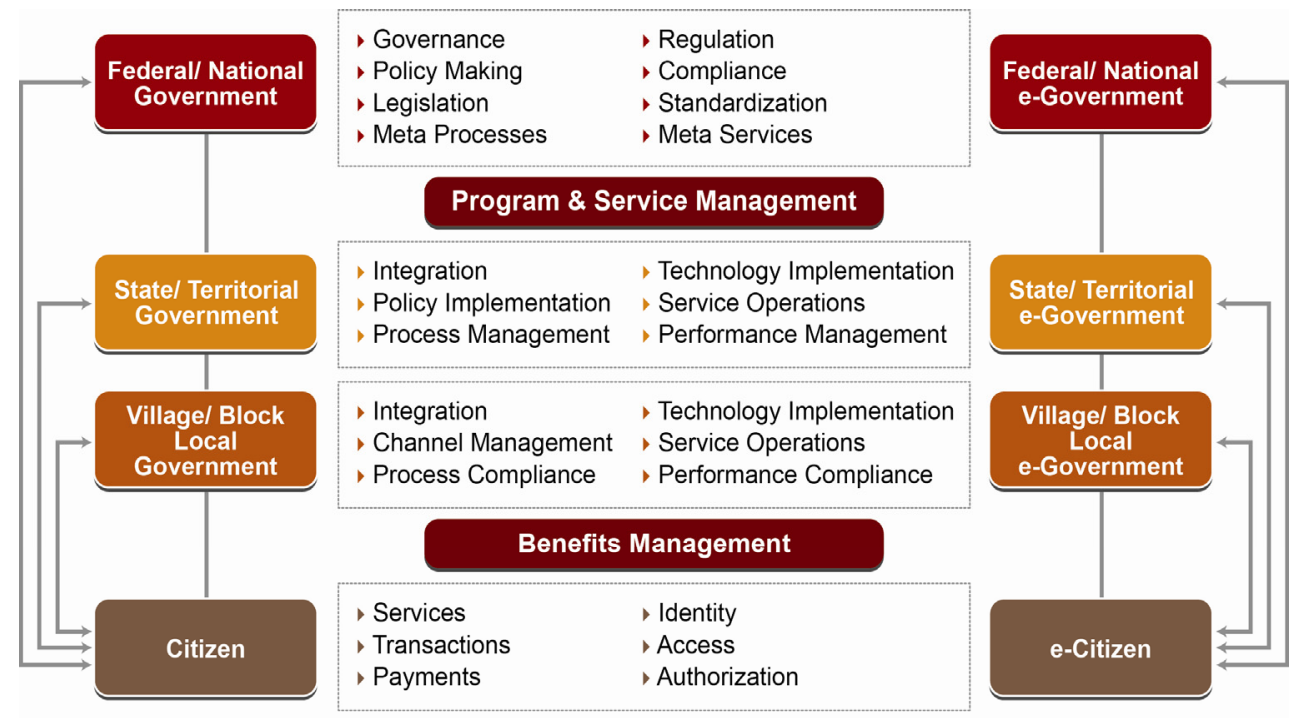

Figure 18. e-Government Aligned with Government

\section{Concluding Remarks}

This article attempted to shed light on some important technological developments that governments need to consider in their e-government strategies and implementation programs. The thoughts presented around these technologies, and the short overview of government implementations in the field of identity management, should be used as a basis for developing a more enriched context to guide practice domains. Indeed, empirical research is imperative to develop more comprehensive understanding and further support the existing body of knowledge.

Overall, e-government is to a great extent associated with the evolving nature of information and communication technologies, which have a consequent impact on the integration and orchestration of services in the digital world. Governments need to shift their orientation from systems to capabilities development, and from merely solving technical issues to creating business impact. Undoubtedly, fragmented legacy IT processes and systems will typically hinder organizational efforts to effectively deliver on business needs. Governments need to re-think public sector jobs in order to keep up with the pace of change and growing technological options. Governments may need to re-invent their businesses, and technology will indeed play a strategic role. However, the road ahead is likely to be very sloppy!

The world we live in today is full of uncertainties and our view of the future is getting foggier as we move forward in time. Hierarchical structures that may have worked at some times in the past are not applicable today. See Figure 19. The world today is more chaotic, where instability is the status quo and the comfort zone in which we live and operate.

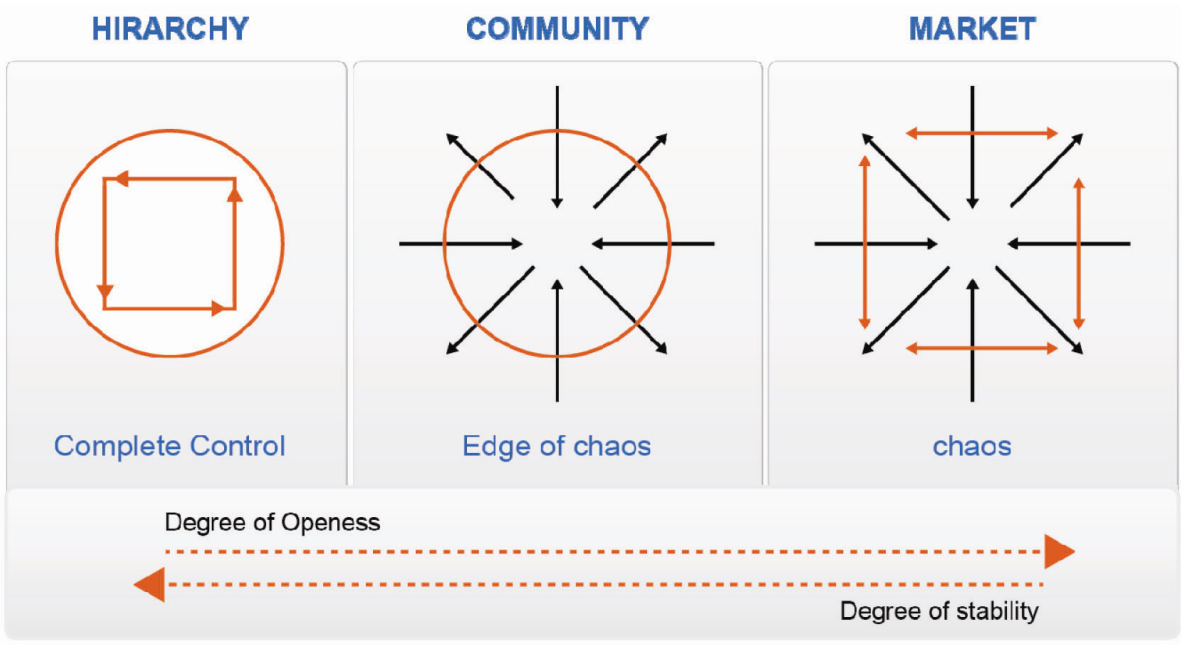

Figure 19. Changing Market Structures 
With such challenges, governments need to change its thinking hat. To truly reap the potential promises of the knowledge economy, governments need to focus more on research and development. This should in turn fuel innovation and improve the scale and magnitude of change needed in light of mind-boggling technological developments.

Governments need to take into consideration the three dimensions of change associated with any new technology: long-term versus short-term impact, big versus little shifts, and technocratic versus political and institutional alterations (West, 2004). Given the complexity of change assessments, it is indeed a difficult exercise to determine how much innovation and how long a period of time is required before something can be considered a "complete change in character, and condition," something that is classically defined as a transformation (West, 2004).

In simple terms, there are five phases of e-government transformation that practitioners need to comprehend, as depicted in Figure 20. Essentially, governments start with a presence on an electronic channel, disseminating information. They move through the maturity stages to reach a utopic state where the citizens are fully empowered and are fully participative in the governing process. While this ideal state is far from reality, the information, interaction, transaction, and involvement stages are a reality within the grasp of implementation. While the level of involvement itself is a function of the type of government in place in a country and is political in nature, the other three stages - information, interaction, and transaction-are commercial in nature and are driven by economic considerations.

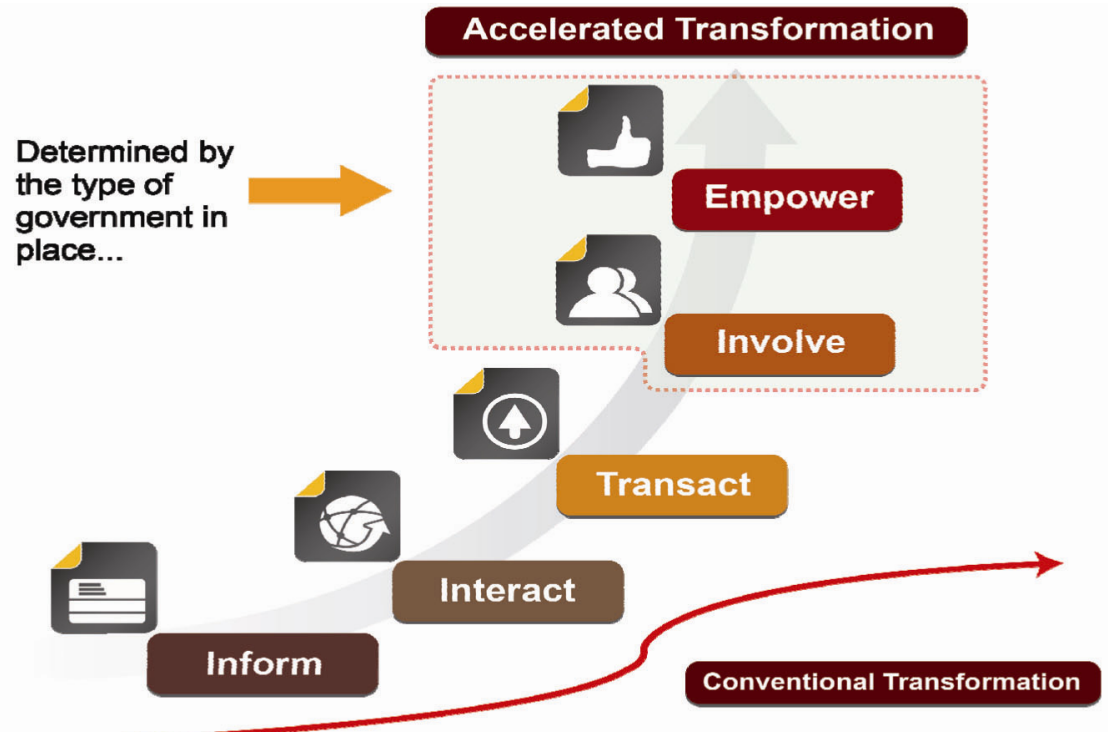

Figure 20. e-Government Transformation Phases

Having said that, we need to spend some quality time to try to teach those around us that e-government is not just about enabling existing processes and using digital means, but rather about rethinking and transforming the ways government institutions operate, with the citizens' benefits and expectations at the core of such re-conceptualization (Capannelli, 2013). Only then may see some success stories of electronic services and transactions crossing boundaries of different government institutions, agencies, and departments. We should also then see some similar stories of vertical and horizontal integration between government systems. Until then, let us do the homework of changing the mindsets of those around us!

\subsection{Limitations \& Directions for Future Research}

The impact of technological development trends and the concept of mobility will have significant impacts on how businesses in both government and the private sector are designed and perform. The ultimate goal in the field of practice will always be focused on achieving higher levels of responsiveness, efficiency, and effectiveness. In light of the evolving technological enablers, the game of change for the better and hence the continuous development of efforts will never end. To avoid re-inventing the wheel, governments and private sector organizations need to share and publish more insightful data about their practices but in a more useful way, i.e., not limiting their reports and published articles to show only the rosy side of what was successfully implemented. Also, organizations must aim to build a more comprehensive body of knowledge around the field of practice. There are few qualitative case studies from within organizations specifically in the government sector. This raises a call for further research and 
investigation. Future research, for example, could be conducted in order to verify the trends identified in this study. Conceivably, some more qualitative case studies of government practices from both emerged and emerging market countries will be useful. Perhaps research from emerging markets is more appealing as organizations in these countries are likely to be interested in innovation and creativity to better position themselves for economic competitiveness and growth.

\section{References}

Abdul, S. (2013). Bring Your Own Device (BYOD) - Provides Tremendous Boost In Employee Satisfaction. Content Loop. [Online] Available: http://www.content-loop.com/bring-your-own-device-byod-provides-tremendous-boost-in-employee-sati sfaction/

Al-Khouri, A.M. \& Bal, J. (2007). Electronic Government in the GCC Countries. International Journal of Social Sciences, 1(2), 83-98. [Online] Available: http://www.waset.org/journals/ijhss/v1/v1-2-13.pdf

Al-Khouri, A.M. (2012). eGovernment Strategies: The Case of the United Arab Emirates. European Journal of ePractice, 17, 126-150. [Online] Available: http://www.epractice.eu/files/Journal_Volume 17-Part11_0.pdf

Al-Khouri, A.M. (2012a). Population Growth and Government Modernisation Efforts. International Journal of Research in Management \& Technology, 2(1), 1-8. [Online] Available: http://www.iracst.org/ijrmt/papers/Vol2no12012/ 1vol2no1.pdf

Al-Khouri, A.M. (2012b). PKI in Government Digital Identity Management Systems. European Journal of ePractice, 4, 4-21. [Online] Available: http://www.epractice.eu/files/Journal_Volume_14_FINAL_28.2.2012_Part3.pdf

Al-Khouri, A.M. (2013). e-Government in Arab Countries: A 6-Staged Roadmap to Develop the Public Sector. Journal of Management and Strategy, 4(1), 80-107. http://dx.doi.org/10.5430/jms.v4n1p80

Andersen, K.V., Henriksen, H.Z. (2005). The First Leg of E-government Research: Domains and Application Areas 1998-2003. Center for Research on IT in Policy Settings (CIPS), Department of Informatics, Copenhagen Business School. [Online] Available: http://www.researchgate.net

APT. (2012). E-Government Implementation in Asia-Pacific Developing Countries and Its Challenges and Obstacles. ASTAP Working Group on Policies, Regulatory and Strategies. Asia-Pacific Telecommunity. [Online] Available: http://www.apt.int/sites/default/files/Upload-files/ASTAP/Rept-5-e-Govt.pdf

Archer, G. (2003). Big Data Strategy - Issues Paper. AIIA Big Data Summit. Australian Government: Department of Finance and Deregulation. [Online] Available: http://agimo.gov.au/files/2013/03/Big-Data-Strategy-Issues-Paper1.pdf.

Aruba Networks (2012). BYOD Adoption is Growing Amongst EMEA Enterprises. [Online] Available: http://www.arubanetworks.com/news-releases/byod-adoption-is-growing

Ashton, K. (2009). That 'Internet of Things' Thing. RFID Journal. [Online] Available: http://www.rfidjournal.com/articles/view?4986

Atkinson, R. (2003). Network Government for the Digital Age. Washington: Progressive Policy Institute.

Azoff, M. (2013). Mobile app development takes center stage as BYOD adoption increases. OVUM. [Online] Available:

http://ovum.com/2013/05/22/mobile-app-development-takes-center-stage-as-byod-adoption-increases/

Barbier, J., Bradley, J., Macaulay, J., Medcalf, R. \& Reberger, C. (2012). BYOD and Virtualization: Top 10 Insights from Cisco IBSG Horizons Study. Cisco. [Online] Available: http://www.cisco.com/web/about/ac79/docs/BYOD.pdf

Baum, C. \& Di Maio. (2000). Gartner's Four Phases of E-Government Model. Gartner Group. [Online] Available: http://www.gartner.com

Bender, A. (2013). Australian government to write big data strategy. [Online] Available: http://www.cio.com.au/article/ 456202/australian_government_write_big_data_strategy

Bornstein, D. (2012). Social Change's Age of Enlightenment. [Online] Available: http://opinionator.blogs.nytimes.com/ 2012/10/17/social-changes-age-of-enlightenment

Brown, M.M. (2003). Electronic Government. In Jack Rabin (ed.). Encyclopedia of Public Administration and Public Policy, Marcel Dekker, 427-432. 
Capannelli, E. (2013). eGovernment Transformation: From Nice-to-Have to Must-Have. [Online] Available: http://www.worldbank.org/en/news/speech/2013/05/31/speech-eGovernment-transformation

Cattie, C. \& Riper, K. (2013). From big data to better decisions. The Business of Federal Technology. [Online] Available: http://fcw.com/articles/2013/03/29/comment-ceb-big-data-decisions.aspx

Cave, J. \& Simmons, S. (2007). Innovative and adaptive pan-European services for citizens in 2010 and beyond: Domain Mapping and Impacts. European Commission, Information Society \& Media DG. [Online] Available: $\mathrm{http} / /$ www.euregov.eu/deliverables/reports/eGov_WP1_D1_domain_mapping.pdf

CDT (2002). The E-Government Handbook for Developing Countries. infoDev, Center for Democracy Technology, Washington, DC. [Online] Available: www.cdt.org/ egov/handbook

Chakravarti, B. \& Venugopal, M. (2008). Citizen Centric Service Delivery through e-Governance Portal. A White Paper published by National Institute for Smart Government, Hyderabad, India. [Online] Available: http://www.nisg.org/knowledgecenter_docs/D01010001.pdf

Chakravorti, B. (2003). The Slow Pace of Fast Change: Bringing Innovations to Market in a Connected World. Harvard Business Review Press.

Christensen, C.M. (1997). The innovator's Dilemma: When New Technologies Cause Great Firms to Fail. Boston, Massachusetts: Harvard Business School Press.

Chui, M., Löffler, M. and Roberts, R. (2010). The Internet of Things. McKinsey Quarterly. [Online] Available: http://www.mckinsey.com/ins ights/high_tech_telecoms_internet/the_internet_of_things

Clayton, H.M. (2003). The Innovator's Solution: Creating and Sustaining Successful Growth. Harvard Business Press.

Clifford, S. (2012). Social Media Are Giving A Voice to Taste Buds. NYTimes.com, 30 July 2012. [Online] Available: $\mathrm{http} / / / \mathrm{www} . n y t i m e s . c o m / 2012 / 07 / 31 /$ technology/facebook-twitter-and-foursquare-as-corporate-focus-groups.ht $\mathrm{ml}$ ? $\mathrm{r}=0$

Colesca, S.E. (2009). Increasing e-Trust: A Solution to Minimize Risk in e-Government Adoption. Journal of Applied Quantitative Methods, 4(1), 31-44. [Online] Available: http://jaqm.ro/issues/volume-4,issue-1/pdfs/colesca.pdf

Collier, D. (2012). 2012 Federal Cloud Review. [Online] Available: http://cagw.org/sites /default/files/pdf/issue-brief-2012-12-cloud-re port-web.pdf

Davenport, T.H. \& Patil, D.J. (2012). Data Scientist: The Sexiest Job of the 21st Century. Harvard Business Review, October, p. 2. [Online] Available: http://hbr.org/2012/10/data-scientist-the-sexiest-job-of-the-21st-century/ar/1

De, R. (2004). E-Government Systems in Developing Countries: Some Research Issues. PreICIS workshop on eGovernment, Washington, December.

Deloitte. (2013). Tech Trends 2013: Elements of Post-digital. [Online] Available: http://www.deloitte.com/assets/ Dcom-UnitedKingdom/Local Assets/Documents/Services/Consulting/uk-c-tech-trends-2013-full-report.pdf

Detica. (2011). The cost of cyber crime: a Detica report in partnership with the office of cyber security and information assurance in the cabinet office. [Online] Available: https://www.gov.uk/government/uploads/ system/uploads/attachment_data/file/60 943/the-cost-of-cyber-crime-full-report.pdf

Devadoss, P.R., Pan, S.L., \& Huang, J.C. (2002). Structurational Analysis of e-Government Initiatives: a Case Study of SCO. Decision Support Systems, (34), 253-269.

Dombrowski, P. \& Gholz, E. (2009). Identifying Disruptive Innovation: Innovation Theory and the Defense Industry. Innovations, 4(2), 101-117. http://dx.doi.org/10.1162/itgg.2009.4.2.101

Drury, A. \& Absalom, R. (2013). BYOD: an emerging market trend in more ways than one. [Online] Available: http://www.logicalis.com/pdf/Logicalis White Paper Ovum(2).pdf

Eggers, W.D. \& Jaffe, J. (2013). Gov on the go: Boosting Public Sector Productivity by Going Mobile. Deloitte University Press. [Online] Available: http://dupress.com/articles/gov-on-the-go

Erl, T., Puttini, R. \& Mahmood, Z. (2013). Cloud Computing: Concepts, Technology \& Architecture. Prentice Hall.

European Commission. (2005). Information Society - eEurope 2005. [Online] Available: http://europa.eu.int/information_society/ eeurope/2005/index_en.htm 
Evans, D. (2011). The Internet of Things: How the Next Evolution of the Internet Is Changing Everything. Cisco Internet Business Solutions Group (IBSG). [Online] Available: http://www.cisco.com/web/about/ac79/ docs/innov/IoT_IBSG_0411FINAL.pdf.

Ferguson, R.B. (2012). It's All About the Platform: What Walmart and Google Have in Common. MIT Sloan Management Review, December 5. [Online] Available: http://sloanreview.mit.edu/improvisations/2012/12/05/ its-all-about-the-platform-what-walmart-and-google-have-in-common

Field, T., Mield, T., Muller, E. \& Law, E. (2003). The e-Government Imperative. Organization for Economic Co-operation and Development, ISBN 92-64-10117-9, Paris, France, 2003. [Online] Available: http:213.253.134.43/oecd/ pdfs/browseit/4203071E.PDF

Furman, S. (2009). Building Trust. [Online] Available: http://www.usability.gov/articles/092009news.html

Gilbert, J. (2012). Confronting Disruptive Innovation. [Online] Available: http://www.lexicon-systems.com/pubs/itinsight/ ITInsight1212.pdf.

Government Business Council (2013). Turning Optimism into Reality: How Big Data Is Transforming Government. [Online] Available: http://cdn.govexec.com/media/gbc/docs/gbc_bah_big_data_lake_insight_report_pub.pdf

Grandy, D. \& Newman, D. (2013). Smartphones and even smarter government. The Age National. [Online] Available:

http://www.theage.com.au/national/public-service/smartphones-and-even-smarter-government-20130503-2iz41. html

Grönlund, Å. (2002). Electronic Government - Design, Applications, and Management. Hershey, PA: Idea Group.

Grönlund, A. \& Horan, T.A. (2004). Introducing e-Gov: History, Definitions, and Issues. Communications of the Association for Information Systems, 15, 713-729.

Hammer, M. \& Champy, J. A. (1993). Reengineering the Corporation: A Manifesto for Business Revolution. New York: Harper Business Books.

Hang, C., \& Kohlbacher, F. (2008). Disruptive innovations and the greying market. Industrial Engineering and Engineering Management Conference, 2-4 December 2007, 1915-1919.

Hay, M. (2003). Managing Big Data. eGov. [Online] Available: http://egov.eletsonline.com/2013/01/managing-big-data/\#sthash.hbzc IbDJ.dpuf

Hayes, B. \& Kotwica, K. (2013). Bring Your Own Device (BYOD) to Work: Trend Report. Elsevier.

Heeks, R. (2002). Informaiton Systems and Development Countries; Failure, Success and Local Improvisation. The Information Society, 18(2), 101-112. http://dx.doi.org/10.1080/01972240290075039

Heeks, R. (2003). Most eGovernment for Development Projects Fail: How can Risks be Reduce?. iGovernment Working Paper Series, Paper no. 14. Manchester: Institute for Development Policy and Management.

Heeks, R. (2006). Analysing the Software Sector in Developing Countries Using Competitive Advantage Theory. Development Informatics Working Paper Series, No.25/2006. Manchester: Institute for Development Policy and Management.

Hughan, K. (2013). Mobile App Adoption is on the Rise, But Not All Retailers Have Caught Up. [Online] Available: http://www.themobileretailblog.com/mobile-commerce-strategies/mobile-app-adoption-is-on-the-rise-but-not-al 1-retailers-have-caught-up

IDC. (2013). IDC Predictions 2013: Competing on the 3rd Platform. [Online] Available: http://www.idc.com/research/Predictions13/downloadable/238044.pdf

Issenberg, S. (2012). How President Obama's Campaign Used Big Data to Rally Individual Voters, Part 1. MIT Technology Review, December $16 . \quad$ [Online] Available: http://www.technologyreview.com/featuredstory/508836/how-obama-used-big-data-to-rally-voters-part-1

Johnson, M. (2011). Mobile Device Management: What you Need to Know for IT Operations Management. Tebbo.

Kalba, K. (2008). The Global Adoption and Diffusion of Mobile Phones. Harvard University. [Online] Available: http://www.pirp.har vard.edu/pubs_pdf/kalba/kalba-p08-1.pdf

Kim, W. C., \& Mauborgne, R. (2005). Blue Ocean Strategy - How to Create Uncontested Market Space and Make the Competition Irrelevant. Boston, MA: Harvard Business School Publishing. 
Klett, G. and Kersten, H. (2012). Mobile Device Management. Verlag: MIT Publishing.

Konkel, F. (2003). Bullish on big data? Better make a plan. [Online] Available: http://fcw.com/Articles/2013/04/01/big-data-booz- allen.aspx?Page=1

Layne, K \& Lee, J. (2001). Developing Fully Functional e-Government: A four Stage Model'. Government Information Quarterly, 18(2), 122-136. http://dx.doi.org/10.1016/S0740-624X(01)00066-1

Ludwig, S. (2012). VentureBeat: Study: Mobile app usage grows 35\%, TV \& web not so much. [Online] Available: $\mathrm{http} / / /$ venturebeat.com/2012/12/05/mobile-app-usage-tv-web-2012/

Manifesto, C. (1999). Social Business Process Reengineering. Harvard Business Review. [Online] Available: $\mathrm{http}: / /$ socialbusinessmanifesto.com/social-business-process-reengineering/

Manyika, J., Chui, M., Brown, B., Bughin, J., Dobbs, R., Roxburgh, C. \& Byers, A.H. (2011). Big data: The next frontier for innovation, competition, and productivity. McKinsey Global Institute. [Online] Available: http://www.mckinsey.com/ /media/McKinsey/dotcom/Insights and pubs/MGI/Research/Technology and Innovation/Big Data/MGI_big_data_full_report.ashx

Mayer-Schonberger, V. \& Cukier, K. (2013). Big Data: A Revolution That Will Transform How We Live, Work, and Think. Eamon Dolan/Houghton Mifflin Harcourt.

McMillan, S. (2010). Legal and Regulatory Frameworks for Mobile Government. Proceedings of mLife 2010 Conferences. October 27-29, Brighton UK. [Online] Available: http://www.egov.vic.gov.au/trends-and-issues/mobile-government/ legal-and-regulatory-frameworks-for-mobile-government.html

Meeker, M. (2010). Internet Trends, Morgan Stanley. [Online] Available: http://www.sherpalo.com/resources/INTERNET_TRENDS_RI_041210[1].pdf

MobiThinking. (2013). Global mobile statistics 2013 Section E: Mobile apps, app stores, pricing and failure rates. [Online] Available: http://mobithinking.com/mobile-marketing-tools/latest-mobile-stats/e\#appusers

Mukherjee, K. \& Sahoo, G. (2010). Cloud Computing: future Framework for eGovernance. International Journal of Computer Applications, 7(7), 31-34. http://dx.doi.org/10.5120/1262-1613

Naseem, S. (2012). Cloud Computing and E-Governance. International Journal of Scientific \& Engineering Research, 3(8), 1-6.

Navarrete, C. (2010). Trust in E-Government Transactional Services: A Study of Citizens' Perceptions in Mexico and the U.S. Proceedings of the 43rd Hawaii International Conference on System Sciences - 2010. [Online] Available: http://www.computer.org/csdl/proceedings/hicss/2010/3869/00/04-05-07.pdf

NIST. (2010). Definition of Cloud Computing. National Institute of Standards and Technology (NIST). [Online] Available: http://csrc.nist.gov/groups/SNS/cloud-computing

Norton. (2012). 2012 NORTON Cybercrime Report. [Online] Available: http://now-static.norton.com/now/en/pu/ images/Promotions/2012/cybercrimeReport/2012_Norton_Cybercrime_Report_Master_FINAL_050912.pdf

OECD. (2009). A Paradigm Shift Towards Citizen Centricity. OECD, Rethinking e-Government Services: User-Centred Approaches. OECD Publishing. http://dx.doi.org/10.1787/9789264059412-2-en

Olson, P. (2013). 10 Predictions For The Mobile Industry In 2013. Forbes. [Online] Available: http://www.forbes.com/sites/parmyolson/2013/01/02/10-predictions-for-the-mobile-industry-in-2013/

Paap, J. \& Katz, R. (2004). Anticipating Disruptive Innovation. Research Technology Management. [Online] Available: http://www.jaypaap.com/articles/Paap-Katz-Disruptive\%20Innovation-sep-04-p13-mod.pdf

Perez, S. (2012). comScore: In U.S. Mobile Market, Samsung, Android Top The Charts; Apps Overtake Web Browsing. [Online] Available: http://techcrunch.com/2012/07/02/comscore-in-u-s-mobile-market-samsung-android-top-the-charts-apps-overta ke-web-browsing/

Piao, M. and Okhuysen, G. (2012). Reexamining the Paradox of Sustaining Innovation and Disruptive Innovation. [Online] Available: https://www.sbrconferences.com/uploads/Nash2012-Piao_Ming.pdf.

Ponemon. (2012). 2012 Cost of Cyber Crime Study: United States, Benchmark Study of U.S. Companies, Ponemon Institute,

Michigan,

USA

[Online]

Available: 
http://www.ponemon.org/local/upload/file/2012_US_Cost_of_Cyber_Crime_Study_FINAL6.pdf

Raftery, T. (2012). Sustainability, Social Media and Big Data. The Energy Collective, 2 November. [Online] Available: http://theenergycollective.com/tom-raftery/138166/sustainability-social-media-and-big-data

Rahav, A. (2011). From user centricity to Citizen Centricity. [Online] Available: http://www.icentered.com/from-user-centricity-to -citizen-centricity

Rannu, R., Saksing, S., Mahlakõiv, T. (2010). Mobile Government: 2010 and Beyond White paper. European Union Regional Development Fund. [Online] Available: http://www.mobisolutions.com/files/Mobile Government 2010 and Beyond v100.pdf

Redman, P., Girard, J. \& Wallin, L. (2011). Magic Quadrant for Mobile Device Management Software. Gartner, [Online] Available: http://www.sap.com/campaigns/2011_04_mobility/assets/GartnerReport_MDM_MQ_April2011.pdf.

Robb, D. (2006). Balancing Sustaining and Disruptive Innovation. Center for Corporate Renewal. [Online] Available: $\mathrm{http}: / /$ www.ctrforcorporaterenewal.com/docs/Balancing Sustaining and Disruptive Innovation.pdf

Sarah, R. (2013). BYOD Recommendations and Dilemmas. Government Technology. [Online] Available: http://www.govtech.com/education/BYOD-Recommendations-and-Dilemmas.html

Satyanarayana, J. (2004). E-Government: The Science of the Possible. India: Prentice Hall.

Scholl, H.J. (ed.) (2010). E-Government: Information, Technology, and Transformation. Armonk, N.Y.: M.E. Sharpe.

Seifert, J.W. (2003). A Primer on E-Government: Sectors, Stages, Opportunities, and Challenges of Online Governance. [Online] Available: http://www.fas.org/sgp/crs/RL31057.pdf

Shailendra, C. Palvia, J. \& Sharma, S.S. (2007). E-Government and E-Governance: Definitions/Domain Framework and Status around the World. Foundations of E-government. [Online] Available: http://www.iceg.net/ 2007/books/1/1_369.pdf

Simić, K., Dadić, J., Paunović, L., Milutinović, M., Bogdanović, Z. (2012). Delivering Mobile Government Services Through Cloud Computing. Anline] Available: http://www.fos.unm.si/media/pdf/Delivering_Mobile_Government_Services_ Through_Cloud_Computing_maj.pdf

Simon, P. (2013). Too Big to Ignore: The Business Case for Big Data. Wiley.

Stanforth, C. (2010). Analysing e-Government Project Failure: Comparing Factoral, Systems and Interpretive Approaches. Centre for Development Informatics, Manchester, UK. [Online] Available: http://www.sed.manchester.ac.uk/ idpm/research/publications/wp/igovernment/documents/iGovWkPpr20.pdf

Su, C., China, W. \& Pei, Z. (2010). Application Model of Mobile E-Government in Wuhan Urban Circle. IEEE International Conference on Multimedia Information Networking and Security (MINES), Nanjing, Jiangsu, 738 $-741$.

Symantec. (2012). State of Mobility Survey. Symantec Corporation. [Online] Available: http://www.symantec.com/content/

en/us/about/media/pdfs/b-state_of_mobility_survey_2012.en-us.pdf?om_ext_cid=biz_socmed_twitter_facebook _marketwire_linkedin_2012Feb_worldwide_StateofMobility

Tellis, G.J. and Golder, P.N. (2003). First to Market, First to Fail? Real Causes of Enduring Market Leadership. In R. Katz (ed.) The Human Side of Managing Technological Innovation. New York: Oxford University Press.

Thames, C. (2011). Business Process Reengineering \& Enterprise Collaboration. [Online] Available: $\mathrm{http}: / / w w w . i s t r y v e . c o m / i m a g e s /$ stories/Stryve_Advisors-_Social_BPR.pdf

Thys, G. and Lacourt, S. (2013). Mobile Payments: Three Steps to NFC Testing Success (White Paper). [Online] Available: http://www.nfcworld.com/wp-content/uploads/2013/05/clear2pay-nfc-mobile-payments-testing-0205.pdf

UNDESA. (2003). e-Government at the Crossroads. World Public Sector Report 2003. United Nations Department of Economic and Social Affairs. United Nations, New York.

UNDESA. (2003). UN Global e-government survey. UNDESA, Division for Public Administration and Development Management, Department for Economic and Social Affairs - UNDESA. [Online] Available: 
http://unpan1.un.org/intradoc/groups/public/documents/un/unpan016066.pdf

van Duivenboden, H.P.M. (2002). Citizen Participation in Public Administration: The Impact of Citizen Oriented Public Services on Government and Citizen, paper presented at the eGovernment Working Group of OECD Public Management Service (PUMA): Paris (March 2002).

Veljanovska, K., Zdravevska, V. (2013). E-Government Based on Cloud Computing. Journal of Emerging Trends in Computing and Information Sciences, 4(4), 377-381.

Warkentin, M., Gefen, D., Pavlou, P.A and Rose, G.M. (2002). Encouraging Citizen Adoption of e-Governnment by Building Trust. Electronic Markets, 12(3), pp.157-162. http://dx.doi.org/10.1080/101967802320245929

West, D.M. (2004). e-Government and Transformation of Service Delivery and Citizen Attitudes. Public Administration Review, 64(1), pp. 15-27. http://dx.doi.org/10.1111/j.1540-6210.2004.00343.x

Whitfield, K. (2013). Fast growth of apps user base in booming Asia Pacific market. Portio Research. [Online] Available: http://www.portioresearch.com/en/blog/2013/fast-growth-of-apps-user-base-in-booming-asia-pacificmarket.aspx

Wiech, D. (2013). The Benefits and Risks Of BYOD. Manufacturing Business Technology. [Online] Available: http://www.mbtmag.com/articles/2013/01/benefits-and-risks-byod

World Bank. (2011). Definition of E-Government. [Online] Available: http://go.worldbank.org/M1JHE0Z280

Yiu, C. (2012). The Big Data Opportunity: Making Government Faster, Smarter and More Personal. Policy Exchange. [Online] Available: http://www.policyexchange.org.uk/images/publications/the big data opportunity.pdf

Zarei, B., Ghapanchi, A \& Sattary, B. (2008). Toward national e-government development models for developing countries: A nine stage model. The International Information and Library Review, 40(1), 199-207. http://dx.doi.org/10.1016/j.iilr.2008.04.001

Zink, T. (2012). The Pros and Cons of BYOD (Bring Your Own Device). CircleID. [Online] Available: http://www.circleid.com/posts/20121010_the_pros_and_cons_of_byod_bring_your_own_device/

\section{Note}

Note 1. NFC is an abbreviation for Near Field Communication, and is a technology in smart phones that can enable contactless transactions and other data exchange with a variety of devices. 